OPEN ACCESS

Edited by:

Sandra Derouiche,

National Institute for Physiological

Sciences (NIPS), Japan

Reviewed by:

Jun Zhou,

German Cancer Research Center

(DKFZ), Germany

Lee J. Martin,

Johns Hopkins University,

United States

Luciene Bruno Vieira,

Federal University of Minas

Gerais, Brazil

*Correspondence:

Yong Ho Kim

euro16@gachon.ac.kr

Chul-Kyu Park

pck0708@gachon.ac.kr

†These authors have contributed equally to this work

Specialty section:

This article was submitted to Signaling,

a section of the journal

Frontiers in Cell and Developmental

Biology

Received: 17 July 2020 Accepted: 06 January 2021

Published: 28 January 2021

Citation:

Hwang S-M, Lee JY, Park C-K and Kim YH (2021) The Role of TRP

Channels and PMCA in Brain Disorders: Intracellular Calcium and pH Homeostasis.

Front. Cell Dev. Biol. 9:584388. doi: 10.3389/fcell.2021.584388

\section{The Role of TRP Channels and PMCA in Brain Disorders: Intracellular Calcium and pH Homeostasis}

\author{
Sung-Min Hwang ${ }^{1 \dagger}$, Ji Yeon Lee ${ }^{2 \dagger}$, Chul-Kyu Park ${ }^{1 *}$ and Yong Ho Kim ${ }^{1 *}$ \\ ${ }^{1}$ Gachon Pain Center, Department of Physiology, Gachon University College of Medicine, Incheon, South Korea, ${ }^{2}$ Gil Medical \\ Center, Department of Anesthesiology and Pain Medicine, Gachon University, Incheon, South Korea
}

Brain disorders include neurodegenerative diseases (NDs) with different conditions that primarily affect the neurons and glia in the brain. However, the risk factors and pathophysiological mechanisms of NDs have not been fully elucidated. Homeostasis of intracellular $\mathrm{Ca}^{2+}$ concentration and intracellular $\mathrm{pH}\left(\mathrm{pH}_{\mathrm{i}}\right)$ is crucial for cell function. The regulatory processes of these ionic mechanisms may be absent or excessive in pathological conditions, leading to a loss of cell death in distinct regions of ND patients. Herein, we review the potential involvement of transient receptor potential (TRP) channels in NDs, where disrupted $\mathrm{Ca}^{2+}$ homeostasis leads to cell death. The capability of TRP channels to restore or excite the cell through $\mathrm{Ca}^{2+}$ regulation depending on the level of plasma membrane $\mathrm{Ca}^{2+}$ ATPase (PMCA) activity is discussed in detail. As PMCA simultaneously affects intracellular $\mathrm{Ca}^{2+}$ regulation as well as $\mathrm{pH}_{\mathrm{i}}$, TRP channels and PMCA thus play vital roles in modulating ionic homeostasis in various cell types or specific regions of the brain where the TRP channels and PMCA are expressed. For this reason, the dysfunction of TRP channels and/or PMCA under pathological conditions disrupts neuronal homeostasis due to abnormal $\mathrm{Ca}^{2+}$ and $\mathrm{pH}$ levels in the brain, resulting in various NDs. This review addresses the function of TRP channels and PMCA in controlling intracellular $\mathrm{Ca}^{2+}$ and $\mathrm{pH}$, which may provide novel targets for treating NDs.

Keywords: TRP channels, brain pathology, neurodegenerative diseases, calcium, pH, homeostasis, neuron

\section{INTRODUCTION}

Calcium $\left(\mathrm{Ca}^{2+}\right)$ is a second messenger involved in numerous signal transduction pathways, including cell proliferation, cell growth, neuronal excitability, metabolism, apoptosis, and differentiation (Berridge et al., 2000; Gleichmann and Mattson, 2011; Maklad et al., 2019). Intracellular $\mathrm{Ca}^{2+}$ has a complex role in brain signaling and regulates brain physiology to maintain neuronal integrity (Marambaud et al., 2009; Bezprozvanny, 2010; Kawamoto et al., 2012). $\mathrm{Ca}^{2+}$ influx across the plasma membrane is important for fundamental brain functions which are mainly mediated by glutamate receptor channels, voltage-gated $\mathrm{Ca}^{2+}$ channels, sodium-calcium exchanger, and transient receptor potential (TRP) channels (Bezprozvanny, 2010; Cross et al., 2010; Gees et al., 2010; Cuomo et al., 2015; Kumar et al., 2016). Thus, $\mathrm{Ca}^{2+}$ signaling affects a variety of neuronal functions in diverse physiological roles, and $\mathrm{Ca}^{2+}$ must be tightly regulated to avoid uncontrolled responses that can lead to pathological conditions (Kumar et al., 2016). However, sustained increase in $\mathrm{Ca}^{2+}$ influx induces endoplasmic reticulum stress, mitochondrial dysfunction, and various proteases, resulting in neuronal cell death 
(Bezprozvanny, 2010; Kawamoto et al., 2012). Indeed, impaired cell function caused by reactive nitrogen (oxygen) species and abnormal $\mathrm{pH}$ homeostasis also underpins the pathophysiology of neurodegenerative diseases (NDs) (Piacentini et al., 2008; Bezprozvanny, 2010; Gleichmann and Mattson, 2011; Zundorf and Reiser, 2011; Harguindey et al., 2017, 2019; Popugaeva et al., 2017). In particular, the maintenance of $\mathrm{Ca}^{2+}$ and $\mathrm{pH}$ levels is involved in a variety of NDs, including Alzheimer's disease (AD), Parkinson's disease (PD), Huntington's disease (HD), amyotrophic lateral sclerosis (ALS), and age-related disorders (Harguindey et al., 2007; Kumar et al., 2009; Smaili et al., 2009; Ruffin et al., 2014; Hong et al., 2020; Thapak et al., 2020). Extensive literature indicates that an excessive increase in cytosolic $\mathrm{Ca}^{2+}$ and $\mathrm{H}^{+}$constitutes both direct and indirect ND-induced processes (Marambaud et al., 2009; Smaili et al., 2009; Bezprozvanny, 2010; Ruffin et al., 2014; Zhao et al., 2016; Harguindey et al., 2017).

TRP channels constitute a large family of membrane $\mathrm{Ca}^{2+}$ channels involved in a wide range of processes including thermoregulation, osmosis, $\mathrm{pH}$, stretch, and chemical signaling (Kaneko and Szallasi, 2014). Functionally, activation of TRP channels influences $\mathrm{Ca}^{2+}$ signaling by allowing $\mathrm{Ca}^{2+}$ to enter the cell (cell depolarization), which may activate voltage-gated $\mathrm{Ca}^{2+}$ channels (Nilius and Owsianik, 2011; Vennekens et al., 2012). TRP channels in neuronal cells regulate voltage-gated $\mathrm{Ca}^{2+}, \mathrm{K}^{+}$, and $\mathrm{Na}^{+}$channels, whereas TRP channel regulation in glial cells results in reduced $\mathrm{Ca}^{2+}$ entry via ORAI by membrane depolarization, or increased $\mathrm{Ca}^{2+}$ influx through the hyperpolarization of the membrane (Gees et al., 2010). In the central nervous system, TRP channels are widely expressed throughout the brain and play an essential role in regulating $\mathrm{Ca}^{2+}$ homeostasis associated with various cellular functions, including synaptic plasticity, synaptogenesis, and synaptic transmission in a specific region of the brain (Venkatachalam and Montell, 2007; Kaneko and Szallasi, 2014; Jardin et al., 2017; Chi et al., 2018; Hong et al., 2020). In addition, TRP subtype channels are expressed simultaneously or separately in neurons and glia, fulfilling critical roles in cell homeostasis, development, neurogenesis, and synaptic plasticity (Vennekens et al., 2012). Several members of the TRP subtype are highly expressed in neurons and glia (Moran et al., 2004; Butenko et al., 2012; Ho et al., 2014; Ronco et al., 2014; Verkhratsky et al., 2014; Liu et al., 2017; Rakers et al., 2017) (Table 1). Thus, diverse TRP channels expressed in the brain are involved in the progression of NDs such as Parkinson's and Alzheimer's. In particular, increased intracellular $\mathrm{Ca}^{2+}$ via TRP channels contributes to various pathophysiological events (Venkatachalam and Montell, 2007; Kaneko and Szallasi, 2014; Moran, 2018; Hong et al., 2020) as well as brain disorders such as $\mathrm{AD}, \mathrm{PD}$, stroke, epilepsy, and migraine (Table 1)(Morelli et al., 2013; Kaneko and Szallasi, 2014; Kumar et al., 2016; Moran, 2018; Hong et al., 2020; Liu et al., 2020).

The normal regulation of intracellular $\mathrm{Ca}^{2+}$ levels involves mechanisms that control the specific uptake and extrusion mechanisms across the cell membrane (Kawamoto et al., 2012; Strehler and Thayer, 2018). $\mathrm{Ca}^{2+}$ influx is mediated by several voltage- and ligand-gated channels as well as transporters.
Conversely, $\mathrm{Ca}^{2+}$ extrusion is dependent on $\mathrm{Ca}^{2+}$ pumps and $\mathrm{Na}^{+} / \mathrm{Ca}^{2+}$ exchangers (Strehler and Thayer, 2018). Among these, plasma membrane $\mathrm{Ca}^{2+}$ ATPases (PMCAs) actively extrude $\mathrm{Ca}^{2+}$ ions out of cells (Boczek et al., 2019). Thus, these pumps are important gatekeepers for maintaining intracellular $\mathrm{Ca}^{2+}$ homeostasis in cells (Stafford et al., 2017; Boczek et al., 2019). However, PMCA dysfunction causes altered $\mathrm{Ca}^{2+}$ homeostasis and leads to a persistent increase in cytosolic $\mathrm{Ca}^{2+}$, which can be neurotoxic and can accelerate the development of NDs and cognitive impairments as the person ages (Strehler and Thayer, 2018; Boczek et al., 2019). In particular, it is possible that the regulation of $\mathrm{Ca}^{2+}$ concentration might be more sensitive in which the cells are expressed both TRP and PMCA in the particular brain region (Figure 1). Thereby, abnormal expression of either TRP or PMCA subtype may be more likely to cause ND than other parts of the brain (Figure 2) (Minke, 2006; Stafford et al., 2017). In addition, PMCA activity is associated with intracellular acidification (Hwang et al., 2011) which is associated with neurological conditions observed among $\mathrm{AD}$ patients and other ND patients (Kato et al., 1998; Hamakawa et al., 2004; Mandal et al., 2012; Ruffin et al., 2014; Tyrtyshnaia et al., 2016).

It is crucial to investigate whether increased $\mathrm{Ca}^{2+}$ and (or) acidification are risk factors that affects ND-induced processes (Chesler, 2003; Hwang et al., 2011; Ruffin et al., 2014; Cuomo et al., 2015; Stafford et al., 2017; Boczek et al., 2019). Here, we review the involvement of TRP channels and PMCA in the pathophysiology of NDs.

\section{BRAIN DISORDERS}

\section{Neurodegenerative Diseases}

NDs such as AD, PD, HD, and ALS are age-related conditions characterized by uncontrolled neuronal death in the brain (Hong et al., 2020; Slanzi et al., 2020; Thapak et al., 2020). To date, several studies have reported that NDs are associated with protein aggregation, oxidative stress, inflammation, and abnormal $\mathrm{Ca}^{2+}$ homeostasis (Sprenkle et al., 2017). The impairment of $\mathrm{Ca}^{2+}$ homeostasis is known to result in increased susceptibility to NDs (Kumar et al., 2009; Smaili et al., 2009; Bezprozvanny, 2010; Gleichmann and Mattson, 2011; Kawamoto et al., 2012; Bagur and Hajnoczky, 2017). In particular, this impairment is associated with changes in $\mathrm{Ca}^{2+}$ buffering capacity, deregulation of $\mathrm{Ca}^{2+}$ channel activity, and alteration in other calcium regulatory proteins that occur in some types of neurons and glial cells in certain brain regions (Zundorf and Reiser, 2011; Nikoletopoulou and Tavernarakis, 2012). There is also increased $\mathrm{Ca}^{2+}$ influx mediated by abnormal TRP channel activation (Sawamura et al., 2017). Similarly, $\mathrm{Ca}^{2+}$ extrusion through PMCA has been shown to decrease in aged neurons (Jiang et al., 2012). For this reason, these NDs are associated with $\mathrm{Ca}^{2+}$ channels in neurons and glial cells (astrocytes, microglia, and oligodendrocytes), which are important for neuronal survival, myelin formation, neuronal support, and regulation of local neuron activity (neurons-glial signaling) (Zhang and Liao, 2015; Cornillot et al., 2019; Enders et al., 2020). 
TABLE 1 | A summary of the transient receptor potential (TRP) subtypes found in distribution of central nervous system (CNS) cell types.

\begin{tabular}{|c|c|c|c|c|c|}
\hline TRP channels & & Expression in brain & Expression in glia & Disorders & References \\
\hline \multirow[t]{5}{*}{$\begin{array}{l}\text { TRPC } \\
\text { subfamily }\end{array}$} & TRPC1 & $\begin{array}{l}\text { - Cerebellum, } \\
\text { hippocampus, } \\
\text { forebrain } \\
\text { - Dopaminergic } \\
\text { neuron (Human/mouse) }\end{array}$ & Astrocyte, microglia, & $\begin{array}{l}\text { NDs, ADs, } \\
\text { PD, HD, }\end{array}$ & $\begin{array}{l}\text { Riccio et al., 2002; Bollimuntha } \\
\text { et al., 2005, 2006; Selvaraj et al., } \\
\text { 2009, 2012; Hong et al., } 2015\end{array}$ \\
\hline & TRPC3 & $\begin{array}{l}\text { - Cerebellum, } \\
\text { hippocampus, } \\
\text { forebrain } \\
\text { - Dopaminergic } \\
\text { neuron (Human) }\end{array}$ & Astrocyte, & $\begin{array}{l}\text { NDs, ADs, } \\
\text { PDs }\end{array}$ & $\begin{array}{l}\text { Rosker et al., 2004; Wu et al., } \\
\text { 2004; Yamamoto et al., 2007; } \\
\text { Mizoguchi et al., } 2014\end{array}$ \\
\hline & TRPC4 & $\begin{array}{l}\text { Cerebellum, } \\
\text { hippocampus, } \\
\text { forebrain }\end{array}$ & Astrocyte, & Epilepsy & $\begin{array}{l}\text { Wang et al., 2007; Wu et al., } \\
\text { 2008; Von Spiczak et al., 2010; } \\
\text { Tai et al., } 2011\end{array}$ \\
\hline & TRPC5 & $\begin{array}{l}\text { - Cerebellum, forebrain } \\
\text { - Hippocampus (mouse) }\end{array}$ & Astrocyte, & $\begin{array}{l}\text { NDs, PDs, } \\
\text { Epilepsy }\end{array}$ & $\begin{array}{l}\text { Shin et al., 2010; Tai et al., 2011; } \\
\text { Kaczmarek et al., } 2012\end{array}$ \\
\hline & TRPC6 & $\begin{array}{l}\text { Cerebellum, } \\
\text { hippocampus, } \\
\text { forebrain, striatum }\end{array}$ & Astrocyte, microglia & NDs, ADs & $\begin{array}{l}\text { Lessard et al., 2005; Wang et al., } \\
\text { 2015; Liu et al., 2017; Lu et al., } \\
2017\end{array}$ \\
\hline \multirow[t]{2}{*}{$\begin{array}{l}\text { TRPM } \\
\text { subfamily }\end{array}$} & TRPM2 & $\begin{array}{l}\text { - Hippocampus, } \\
\text { forebrain } \\
\text { - Cerebellum (human), } \\
\text { cortex (rat) }\end{array}$ & Astrocyte, microglia & $\begin{array}{l}\text { NDs, ADs, } \\
\text { PDs }\end{array}$ & $\begin{array}{l}\text { Fonfria et al., 2005; Kaneko } \\
\text { et al., 2006; Hermosura et al., } \\
\text { 2008; Ostapchenko et al., } 2015\end{array}$ \\
\hline & TRPM7 & $\begin{array}{l}\text { - Cerebellum, } \\
\text { forebrain, } \\
\text { - Hippocampus } \\
\text { (human) } \\
\text { - cortex (mouse) }\end{array}$ & Astrocyte, microglia & $\begin{array}{l}\text { NDs, ADs, } \\
\text { PDs, Epilepsy }\end{array}$ & $\begin{array}{l}\text { Aarts and Tymianski, 2005; } \\
\text { Hermosura et al., 2005; Chen X. } \\
\text { et al., 2010; Coombes et al., } \\
\text { 2011; Oakes et al., } 2019\end{array}$ \\
\hline \multirow[t]{2}{*}{$\begin{array}{l}\text { TRPV } \\
\text { subfamily }\end{array}$} & TRPV1 & $\begin{array}{l}\text { - Basal ganglia, } \\
\text { hindbrain Cerebellum } \\
\text { - Hippocampus (rat/mouse), }\end{array}$ & Astrocyte, microglia & $\begin{array}{l}\text { NDs, AD, HD, } \\
\text { epilepsy }\end{array}$ & $\begin{array}{l}\text { Lastres-Becker et al., 2003; Kim } \\
\text { et al., 2005; Gibson et al., 2008; } \\
\text { Li et al., 2008; Lee et al., 2011; } \\
\text { Balleza-Tapia et al., } 2018\end{array}$ \\
\hline & TRPV4 & $\begin{array}{l}\text { Cerebellum, } \\
\text { hippocampus, }\end{array}$ & Astrocyte, microglia & NDs, AD, & $\begin{array}{l}\text { Auer-Grumbach et al., 2010; } \\
\text { Chen D. H. et al., 2010; } \\
\text { Landoure et al., 2010; Klein } \\
\text { et al., 2011; Wang et al., } 2019\end{array}$ \\
\hline $\begin{array}{l}\text { TRPA } \\
\text { subfamily }\end{array}$ & TRPA1 & $\begin{array}{l}\text { Cerebellum, } \\
\text { hippocampus, }\end{array}$ & Astrocyte, oligodendrocyte & $A D$ & $\begin{array}{l}\text { Shigetomi et al., 2011; Lee et al., } \\
\text { 2016; Saghy et al., 2016; } \\
\text { Bolcskei et al., } 2018\end{array}$ \\
\hline
\end{tabular}

PMCA, plasma membrane $\mathrm{Ca}^{2+}$ ATPase; AD, Alzheimer's disease; PD, Parkinson's disease; ND, neurodegenerative disease.

\section{Pathophysiological Role of TRP Channels}

TRP channels are non-selective, $\mathrm{Ca}^{2+}$-permeable channels that regulate diverse cellular functions in neurons (Nilius, 2007; Venkatachalam and Montell, 2007; Sawamura et al., 2017). Based on functional characterization of TRP channels by a wide range of stimuli (Zheng, 2013), aberrant activity of TRP channels likely initiates and/or propagates ND processes, especially cell death, via increased intracellular $\mathrm{Ca}^{2+}$ in various brain regions (Moran, 2018; Hong et al., 2020; Huang et al., 2020). Here, we focus on the function of TRP channels associated with $\mathrm{Ca}^{2+}$ signaling in neurons and glial cells (Figure 1A) (Nilius, 2007; Bollimuntha et al., 2011; Zheng, 2013; Zhang and Liao, 2015; Jardin et al., 2017; Sawamura et al., 2017; Hasan and Zhang, 2018; Samanta et al., 2018; Cornillot et al., 2019; Enders et al., 2020; Wang et al., 2020). Based on sequence homology, the TRP family currently comprises 28 mammalian channels and is subdivided into six subfamilies: TRP canonical (TRPC),
TRP vanilloid (TRPV), TRP ankyrin (TRPA), TRP melastatin (TRPM), TRP polycystin (TRPP), and TRP mucolipin (TRPML) (Nilius, 2007; Selvaraj et al., 2010; Nishida et al., 2015; Sawamura et al., 2017). Most TRP channels are non-selective channels with consistent $\mathrm{Ca}^{2+}$ permeability (Samanta et al., 2018) and each TRP subtype responds to various temperatures, ligands, as well as specific agonists and activators (Figure 1B) (Luo et al., 2020). TRP channels are tetramers formed by monomers that share a common structure comprising six transmembrane domains and containing cation-selective pores (Hellmich and Gaudet, 2014). Numerous studies have reported that these TRP channels are related to neuronal cell death that is associated with abnormal $\mathrm{Ca}^{2+}$ homeostasis (Gees et al., 2010; Sawamura et al., 2017).

\section{TRPC (Classic or Canonical)}

TRPC was the first TRP group identified in mammals (Selvaraj et al., 2010). The TRPC subfamily contains members: TRPC1-7 


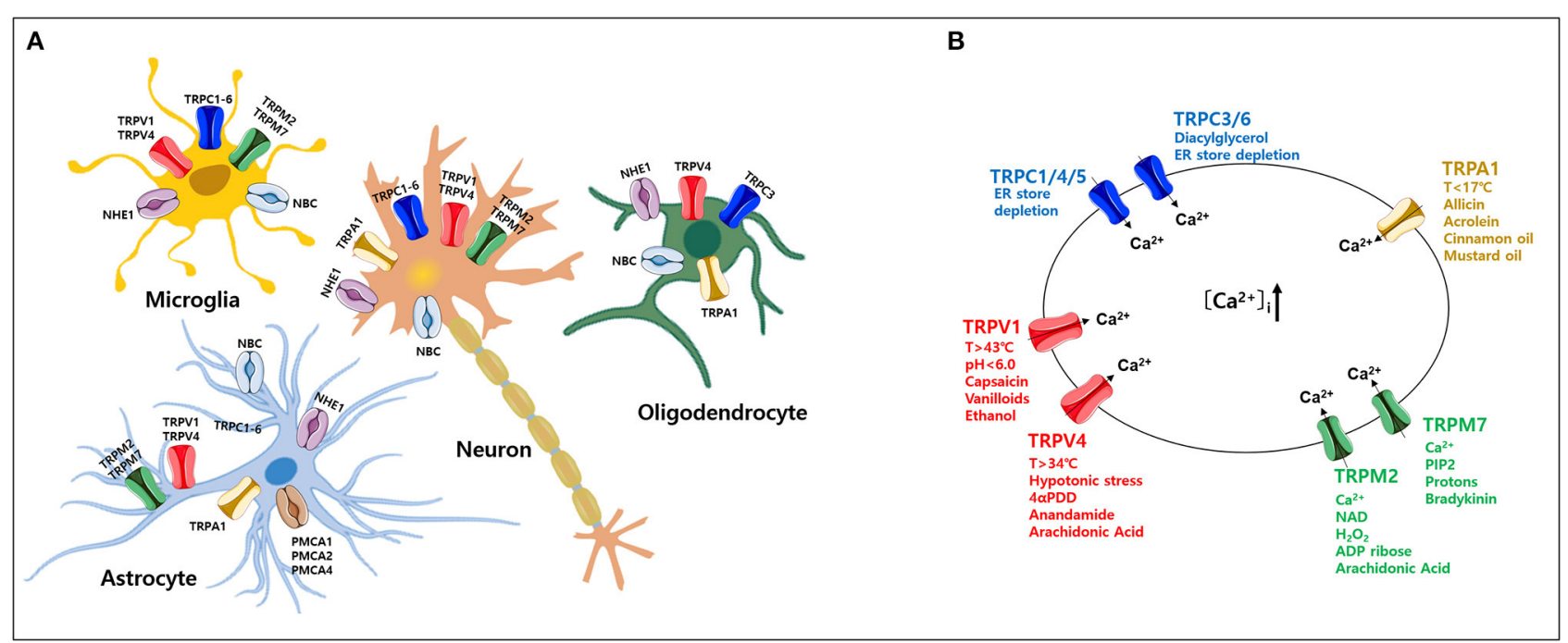

FIGURE 1 | Expression of various transient receptor potential (TRP) subtypes and calcium $\left(\mathrm{Ca}^{2+}\right)$ influx by their agonists in the mammalian central nervous system (CNS). (A) Expression profile of various TRP channels, NHE1, and NBC, in mammalian CNS cell types. (B) $\mathrm{Ca}^{2+}$ influx through activation of TRP subtypes by various agonists or activators in the mammalian CNS. TRP, transient receptor potential; PMCA, plasma membrane $\mathrm{Ca}^{2+}$ ATPase; $\mathrm{NBC}, \mathrm{Na}^{+} / \mathrm{HCO}_{3}^{-}$cotransporters; $\mathrm{NHE}$, $\mathrm{Na}^{+} / \mathrm{H}^{+}$exchangers.
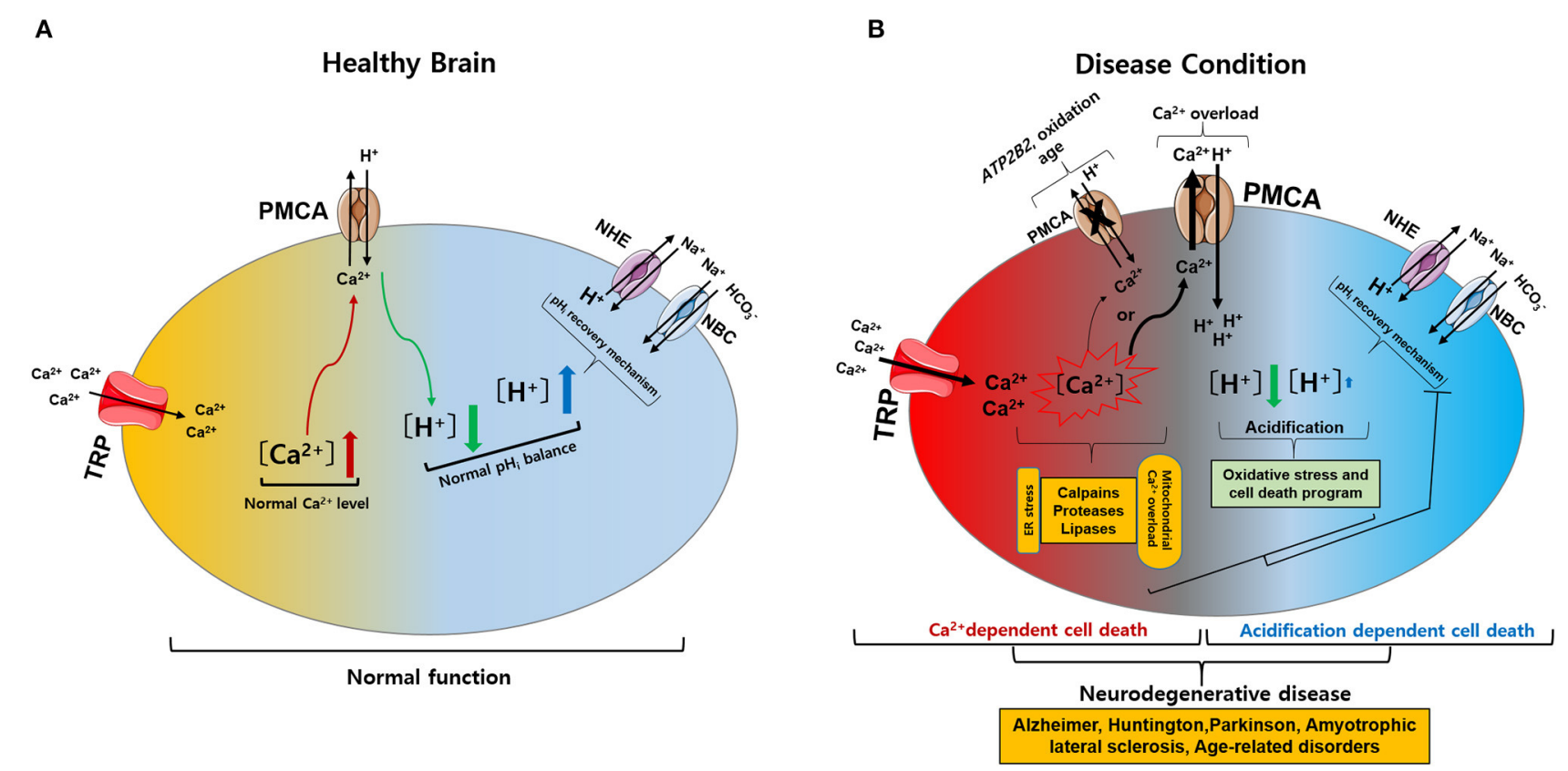

FIGURE 2 | Intracellular calcium $\left(\mathrm{Ca}^{2+}\right)$ and $\mathrm{pH}\left(\mathrm{pH}_{\mathrm{i}}\right)$ signaling by activation of TRP and PMCA in healthy and diseased condition of the brain. (A) Normal physiological function of intracellular $\mathrm{Ca}^{2+}$ and $\mathrm{pH}_{\mathrm{i}}$ homeostasis. The activation of TRP channels leads to $\mathrm{Ca}^{2+}$ influx into the cytosol. Increased $\mathrm{Ca}^{2+}$ levels are regulated by PMCA. The activation of PMCA can cause acidification. Acidification conditions are mediated by $\mathrm{pH}_{\mathrm{i}}$ recovery functions regulated by NBC and NHE. (B) Neurodegenerative diseases caused by pathophysiological functions of intracellular $\mathrm{Ca}^{2+}$ and $\mathrm{pH}_{\mathrm{i}}$ homeostasis. (1) The activation of TRP channels leads to excess Ca ${ }^{2+}$ influx and overload $\mathrm{Ca}^{2+}$ is maintained due to ATP2B2, oxidation, and age-related downregulation of PMCA: $\mathrm{Ca}^{2+}$-dependent cell death. (2) PMCA overexpression due to cytoplasmic $\mathrm{Ca}^{2+}$ overload cause persistent acidification from inhibition of the $\mathrm{pH}_{\mathrm{i}}$ recovery mechanism by oxidative stress or cell death program: acidification dependent cell death. Ultimately, abnormal intracellular $\mathrm{Ca}^{2+}$ and $\mathrm{pH}_{\mathrm{i}}$ levels impair neuronal function, resulting in neurodegenerative diseases. TRP, transient receptor potential; PMCA, plasma membrane $\mathrm{Ca}^{2+}$ ATPase; $\mathrm{NBC}, \mathrm{Na}^{+} / \mathrm{HCO}_{3}^{-}$cotransporters; $\mathrm{NHE}, \mathrm{Na}^{+} / \mathrm{H}^{+}$exchangers. 
(Wang et al., 2020). With the exception of TRPC2, all TRPC channels are widely expressed in the brain from the embryonic period to adulthood (Douglas et al., 2003). TRPC channels can form functional channels by heteromeric interactions, functioning as non-selective $\mathrm{Ca}^{2+}$ entry channels with distinct activation modes (Villereal, 2006). Thus, TRPC channels play an important role in regulating basic neuronal processes. TRPC1 is highly expressed and involved in the early development and proliferation of neurons (Yamamoto et al., 2005; Hentschke et al., 2006) as well as synaptic transmission (Broker-Lai et al., 2017; Wang et al., 2020). TRPC1 and TRPC4 have been reported to regulate neuronal cell death in response to seizures in the hippocampus and septum (Broker-Lai et al., 2017). The TRPC1/4/5 channel has been expressed in the somatosensory cortex, hippocampus, and motor cortex of adult rats (Riccio et al., 2002; Moran et al., 2004; Fowler et al., 2007). In particular, the dense expression of TRPC3 regulates hippocampal neuronal excitability and memory function (Neuner et al., 2015). The abnormal increase in sustained cytosolic $\mathrm{Ca}^{2+}$ by TRPC5 activation causes neuronal damage through the calpaincaspase-dependent pathway and the CaM kinase as seen in HD (Hong et al., 2015). Spinocerebellar ataxia type 14 (SCA14) is an autosomal dominant ND caused by a mutation in protein kinase C $\gamma$ (Wong et al., 2018). This mutation of SCA14 has been demonstrated to cause phosphorylation failure in TRPC3 channels, resulting in persistent $\mathrm{Ca}^{2+}$ entry that may contribute to neurodegeneration (Adachi et al., 2008). On the other hand, TRPC3 or TRPC6 promotes neurotrophin action on brainderived neurotrophic factor (BDNF) by improving neuronal survival through $\mathrm{Ca}^{2+}$ influx (Huang et al., 2011). All TRPC channels are expressed in astrocytes and TRPC1 and TRPC3 play a critical role in astrocyte store-operated $\mathrm{Ca}^{2+}$ entry, which is induced by endoplasmic reticulum depletion (Verkhratsky et al., 2014). TRPC1 and TRPC6 are also expressed in rat microglia (Zhang and Liao, 2015). Thus, some TRPC channels exhibit different functions in normal physiological or pathological events, depending on $\mathrm{Ca}^{2+}$ signaling in the brain (Huang et al., 2011; Li et al., 2012; Neuner et al., 2015).

\section{TRPM (Melastatin)}

Of all TRP channels, the TRPM subfamily has the largest and most diverse expression levels and has been strongly implicated in NDs (Samanta et al., 2018). The TRPM channel consists of eight members (TRPM1-8) and shares common structural characteristics with other TRP channels (Huang et al., 2020). However, they have a variety of C-terminal sections with active enzyme domains and a unique $\mathrm{N}$-terminal without ankyrin repeats involved in channel assembly and trafficking (Huang et al., 2020). A distinctive feature of TRPM channels is the regulation of $\mathrm{Ca}^{2+}$ and magnesium $\left(\mathrm{Mg}^{2+}\right)$ homeostasis, and TRPM (2-7) are mainly expressed in the CNS. In addition, TRPM2 is activated by a wide range of factors including $\mathrm{NAD}^{+}$-related metabolites, adenosine diphosphateribose, oxidative stress, and depletion of glutathione (GSH) (Sita et al., 2018). Increased levels of reactive oxygen species (ROS) due to GSH depletion causes TRPM2-dependent $\mathrm{Ca}^{2+}$ influx to induce neuronal cell death, suggesting that several neurological disorders, including $\mathrm{AD}, \mathrm{PD}$, and bipolar disorder (Akyuva and Naziroglu, 2020). In addition, an increase in intracellular $\mathrm{Ca}^{2+}$ and $A \beta$ induced by TRPM2 activity induces neuronal cell death in the rat striatum (Belrose and Jackson, 2018). $\mathrm{Mg}^{2+}$ is the second most abundant cation and essential cofactor in various enzymatic reactions (Ryazanova et al., 2010). TRPM2 is expressed by both microglia and astrocytes, which regulate gliosis and immune cell function (Wang et al., 2016; Huang et al., 2017). TRPM7 is permeable to $\mathrm{Mg}^{2+}$ and maintains $\mathrm{Mg}^{2+}$ homeostasis (Ryazanova et al., 2010). In mouse cortical neurons, inhibition of TRPM7 expression protects against neuronal cell damage (Asrar and Aarts, 2013; Huang et al., 2020). TRPM7 is also found in astrocytes and microglia to control migration, proliferation, and invasion (Siddiqui et al., 2014; Zeng et al., 2015).

\section{TRPV (Vanilloid)}

TRPV channels form homo- or heterotetrameric complexes and are non-selective cation channels (Startek et al., 2019). The TRPV subfamily consists of six members (TRPV1-6) that are located mostly on the plasma membrane (Zhai et al., 2020). Recent studies on pathological TRPV1 expression in the brain have been performed (Mickle et al., 2015). TRPV1 activation induces caspase-3 dependent programmed cell death through $\mathrm{Ca}^{2+}$ mediated signaling, resulting in cell death of cortical neurons (Ho et al., 2012; Song et al., 2013) and also triggers cell death through L-type $\mathrm{Ca}^{2+}$ channels and $\mathrm{Ca}^{2+}$ influx in rat cortical neurons (Shirakawa et al., 2008). The activation of cannabinoid 1 (CB1) receptors stimulates TRPV1 activity, leading to increased intracellular $\mathrm{Ca}^{2+}$ and cell death of mesencephalic dopaminergic neurons (Kim et al., 2005, 2008). TRPV1 activation induces apoptotic cell death in rat cortical neurons, leading to chronic epilepsy distinguished by abnormal brain activity ( $\mathrm{Fu}$ et al., 2009). TRPV1 activation in microglia plays a positive role in promoting microglial phagocytosis in damaged cells while disrupting mitochondria and increasing ROS production (Kim et al., 2006; Hassan et al., 2014). TRPV1 has been shown to affect the migration of astrocytes (Ho et al., 2014). Abnormal function of TRPV4 leads to neuronal dysfunction and axonal degeneration due to increased $\mathrm{Ca}^{2+}$ via $\mathrm{Ca}^{2+} /$ calmodulin-dependent protein kinase II (CaMKII) (Woolums et al., 2020). TRPV4 plays a role in regulating the osmotic pressure in the brain and is highly expressed throughout glial cells associated with ND (Liedtke and Friedman, 2003; Rakers et al., 2017). Thus, these channels play an important role in $\mathrm{Ca}^{2+}$ homeostasis and are therapeutic targets for various disorders.

\section{TRPA (Ankyrin)}

TRPA1 was first identified as an ankyrin-like transmembrane protein and the solitary member of the mammalian TRPA subfamily (Yang and Li, 2016). TRPA1 is a non-selective cation channel formed by homo- or heterotetramer subunits with a cytosolic $\mathrm{N}$-terminal domain (16 ankyrin repeat sequence) and C-terminal $\mathrm{Ca}^{2+}$-binding domains (Nilius et al., 2011; Fernandes et al., 2012). The TRPA1 channel responds to a variety of ligands, such as temperature, osmotic changes, and endogenous compounds (Nishida et al., 2015). To date, the reported role of TRPA1 in neurons is the mediation of pain, 
cold, inflammation, and itch sensation (Fernandes et al., 2012). Recent reports indicate that TRPA1 hyperactivation causes $A \beta$ oligomer-mediated rapid $\mathrm{Ca}^{2+}$ signaling (Bosson et al., 2017; Hong et al., 2020). Additionally, ablation of TRPA1 in APP/PS1 transgenic mice attenuated the progression of $\mathrm{AD}$, improved learning and memory conditions, and reduced $A \beta$ plaques and cytokines (Lee et al., 2016). Similarly, TRPA1 channels promote $\mathrm{Ca}^{2+}$ hyperactivity of astrocytes and then contribute to synaptic dysfunction due to the oligomeric forms of $\mathrm{A} \beta$ peptide (Lee et al., 2016; Bosson et al., 2017; Logashina et al., 2019; Alavi et al., 2020). In addition, TRPA 1 mediates $\mathrm{Ca}^{2+}$ signaling in astrocytes, resulting in dysregulation of synaptic activity in $\mathrm{AD}$ (Bosson et al., 2017).

\section{Other Channels}

TRPML and TRPP have limited similarity to other TRP family members (Samanta et al., 2018; Huang et al., 2020). TRPML channels (TRPML1-3) are $\mathrm{Ca}^{2+}$ permeable cation channels that each contain six transmembrane segments with helices (S1-S6) and a pore site comprised of S5, S6, and two pore helices (PH1 and PH2) (Schmiege et al., 2018; Tedeschi et al., 2019). TRPML channels are mostly located in intracellular compartments instead of the plasma membrane (Clement et al., 2020). TRPP channels share high protein sequence similarity with TRPML channels and are located in the primary cilia consisting of TRPP1 (also known as PKD1) and TRPP2 (PKD2) (Samanta et al., 2018). To date, evidence indicates that various TRP channels are expressed in the CNS and play important roles in the development of several NDs (Sawamura et al., 2017; Samanta et al., 2018). In particular, TRP channels and $\mathrm{Ca}^{2+}$ homeostasis (Bezprozvanny, 2010) are likely to underpin $\mathrm{Ca}^{2+}$ dependent neuronal death in NDs (Sawamura et al., 2017; Hong et al., 2020).

\section{PATHOPHYSIOLOGICAL ROLE OF PLASMA MEMBRANE CALCIUM ATPases}

Of the various proteins involved in $\mathrm{Ca}^{2+}$ signaling, PMCA is the most sensitive $\mathrm{Ca}^{2+}$ detector that regulates $\mathrm{Ca}^{2+}$ homeostasis (Boczek et al., 2019). PMCA exists in four known isoforms (Boczek et al., 2019). In both mice and humans, PMCAs 14 exhibit anatomically distinct expression patterns, such that isoforms 1 and 4 are ubiquitously expressed in all tissue types, whereas PMCA2 and PMCA3 are tissue-specific and exclusive in neurons of the brain (Kip et al., 2006). In addition, PMCA1, 2 , and 4 were detected in rat cortical astrocytes (Fresu et al., 1999) (Table 2). The general structure of PMCA consists of 10 transmembrane domains (TM) with the $\mathrm{N}$ - and C-terminal ends on the cytosolic side (Stafford et al., 2017). The physiological functions of PMCA include the regulation and maintenance of optimal $\mathrm{Ca}^{2+}$ homeostasis (Bagur and Hajnoczky, 2017). PMCA is an ATP-driven $\mathrm{Ca}^{2+}$ pump that maintains low resting intracellular $\mathrm{Ca}^{2+}$ concentration $\left(\left[\mathrm{Ca}^{2+}\right] \mathrm{i}\right)$ to prevent cytotoxic $\mathrm{Ca}^{2+}$ overload-mediated cell death through activation of ion channels such as TRP (Zundorf and Reiser, 2011). In addition, PMCA is involved in $\mathrm{Ca}^{2+}$-induced intracellular acidification by countertransport of $\mathrm{H}^{+}$ions (Vale-Gonzalez et al., 2006; Majdi et al., 2016). Thus, PMCA plays a vital role in controlling cell survival and cell death (Stafford et al., 2017). PMCA expression changes significantly during brain development

TABLE 2 | A summary of the transient receptor potential (TRP) subtypes found in distribution of central nervous system (CNS) cell types.

\begin{tabular}{|c|c|c|c|c|}
\hline PMCA subfamily & Expression in brain & $\begin{array}{l}\text { Expression } \\
\text { in glia }\end{array}$ & Disorders & References \\
\hline PMCA1 & $\begin{array}{l}\text { - Ubiquitous in brain } \\
\text { (human and rat). } \\
\text { - Cerebellum, cerebral } \\
\text { cortex, brain } \\
\text { stem (Human) }\end{array}$ & $\begin{array}{l}\text { Rat cortical } \\
\text { astrocytes }\end{array}$ & $A D, P D$ & $\begin{array}{l}\text { Stauffer et al., 1995; } \\
\text { Fresu et al., 1999; Brini } \\
\text { et al., } 2013\end{array}$ \\
\hline PMCA2 & $\begin{array}{l}\text { - Cerebellar purkinje } \\
\text { neurons (human/mouse) } \\
\text { - cerebellum, cerebral } \\
\text { cortex, brain } \\
\text { stem (Human) }\end{array}$ & $\begin{array}{l}\text { Rat cortical } \\
\text { astrocytes }\end{array}$ & $\begin{array}{l}\mathrm{AD}, \mathrm{PD} \text {, cerebellar } \\
\text { ataxias, sensory } \\
\text { neuron diseases }\end{array}$ & $\begin{array}{l}\text { Stauffer et al., 1995; } \\
\text { Fresu et al., 1999; } \\
\text { Kurnellas et al., 2007; } \\
\text { Empson et al., 2010; } \\
\text { Hajieva et al., 2018; } \\
\text { Strehler and Thayer, } \\
2018\end{array}$ \\
\hline PMCA3 & $\begin{array}{l}\text { - Cerebellum, cerebral } \\
\text { cortex (Human) } \\
\text { - Cerebellum and } \\
\text { hippocampus (Rat) }\end{array}$ & Limited & $\begin{array}{l}\text { Cerebellar ataxias, } \\
\text { sensory neuron } \\
\text { diseases }\end{array}$ & $\begin{array}{l}\text { Stauffer et al., 1995; } \\
\text { Zanni et al., 2012; } \\
\text { Strehler and Thayer, } \\
2018\end{array}$ \\
\hline PMCA4 & $\begin{array}{l}\text { - Ubiquitous in } \\
\text { brain (human/rat) } \\
\text { - Cerebellum, cerebral } \\
\text { cortex, brain } \\
\text { stem (Human) }\end{array}$ & $\begin{array}{l}\text { Rat cortical } \\
\text { astrocytes }\end{array}$ & $A D, P D$ & $\begin{array}{l}\text { Stauffer et al., 1995; } \\
\text { Fresu et al., 1999; Brini } \\
\text { et al., 2013; Zaidi et al., } \\
2018\end{array}$ \\
\hline
\end{tabular}

PMCA, plasma membrane Ca ${ }^{2+}$ ATPase; AD, Alzheimer's disease; PD, Parkinson's disease. 
(Boczek et al., 2019). One of the characteristics of brain aging is a $\mathrm{Ca}^{2+}$ homeostasis disorder, which can result in detrimental consequences on neuronal function (Boczek et al., 2019). Overall, PMCAs have been attributed a housekeeping role in maintaining intracellular $\mathrm{Ca}^{2+}$ levels through precise regulation of $\mathrm{Ca}^{2+}$ homeostasis (Strehler et al., 2007). However, the altered composition of PMCA is associated with a less efficient $\mathrm{Ca}^{2+}$ extrusion system, increasing the risk of neurodegenerative processes (Strehler and Thayer, 2018). ATP2B2 is a deafnessassociated gene that encodes PMCA2 (Smits et al., 2019). A recent study reported a link between PMCA2 and autism spectrum disorder (ASD) (Yang et al., 2013). ASD is a group of neurodevelopmental disorders that results in deficits in social interaction (Chaste and Leboyer, 2012; Fatemi et al., 2012). Intracellular $\mathrm{Ca}^{2+}$ levels are crucial for regulating neuronal survival, differentiation, and migration (Bezprozvanny, 2010). Perturbations in these processes underlie the pathogenesis of autism spectrum disorders (Gilbert and Man, 2017). ATP2B3 mutations are associated with X-linked cerebellar ataxia and $\mathrm{Ca}^{2+}$ extrusion disorders in patients with cerebellar ataxia and developmental delay (Zanni et al., 2012; Mazzitelli and Adamo, 2014; Cali et al., 2015). Several neurotoxic agents, such as oxidation and age, downregulate PMCA function and increase susceptibility to NDs (Zaidi, 2010). In particular, the internalization of PMCA2 initiated by protease function in rat hippocampal pyramidal cells after glutamate exposure or kainateinduced seizures, in which loss of PMCA function occurs, may contribute to $\mathrm{Ca}^{2+}$ dysregulation and lead to neuronal cell death (Pottorf et al., 2006; Stafford et al., 2017). A decrease in PMCA activity and increased $\mathrm{Ca}^{2+}$ may cause cell death depending on the degree of cytosolic accumulation of tau and $\mathrm{A} \beta$ in $\mathrm{AD}$ (Boczek et al., 2019). In addition, PMCA expression is decreased in the cortex of postmortem brains of patients with $\mathrm{AD}$ (Berrocal et al., 2019; Boczek et al., 2019).

\section{pH REGULATION BY PMCA IN NEURODEGENERATIVE DISEASES}

As mentioned above, PMCAs have a $\mathrm{Ca}^{2+}$ extrusion function on the membrane and another important function, namely $\mathrm{H}^{+}$ uptake (Stafford et al., 2017). Since PMCA is responsible for control of $\mathrm{Ca}^{2+}$ extrusion and $\mathrm{H}^{+}$uptake rates, it provides an important link between $\mathrm{Ca}^{2+}$ signaling and intracellular $\mathrm{pH}\left(\mathrm{pH}_{\mathrm{i}}\right)$ in neurons (Hwang et al., 2011). Mechanisms that maintain strict $\mathrm{pH}$ homeostasis in the brain control neuronal excitability, synaptic transmission, neurotransmitter uptake, nociception, and inflammation (Chesler, 2003; Dhaka et al., 2009; Casey et al., 2010; Hwang et al., 2011). Changes in $\mathrm{pH}$ caused via $\mathrm{pH}$-sensitive or $\mathrm{pH}$-regulated ion channels are detrimental to brain function and can cause multiple degenerative diseases (Ruffin et al., 2014). Neuronal excitability is particularly sensitive to changes in intracellular and extracellular $\mathrm{pH}$ mediated by various ion channels (Parker and Boron, 2013). The activation of TRPV1 has been reported to induce a rise in $\mathrm{Ca}^{2+}$ and cause intracellular acidification via the activation of PMCA in the rat trigeminal ganglion (Hwang et al., 2011). Under normal conditions, acidification conditions are promptly returned to and maintained at normal $\mathrm{pH}$ levels through a physiological $\mathrm{pH}_{\mathrm{i}}$ recovery mechanism involving the regulation of $\mathrm{Na}^{+} / \mathrm{H}^{+}$exchangers $(\mathrm{NHE})$ and $\mathrm{Na}^{+}-\mathrm{HCO}_{3}^{-}$ cotransporter (NBCs) in the brain (Chesler, 2003; Sinning and Hubner, 2013; Ruffin et al., 2014; Bose et al., 2015). NHE1 is abundantly expressed in all neuronal cells and astrocytes, regulating cell volume homeostasis and $\mathrm{pH}_{\mathrm{i}}$ (Song et al., 2020). $\mathrm{NBC1}$ is also widely expressed in astrocytes throughout the brain (Annunziato et al., 2013) (Figure 1A). However, functional inhibition of $\mathrm{pH}_{\mathrm{i}}$ recovery mechanism in pathological conditions leads to excessive intracellular acidification (Majdi et al., 2016). Therefore, although the exact underlying mechanism that causes intracellular acidification in brain neurons is unknown. However, it appears that persistent intracellular acidification condition promotes irreversible neuronal damage and induces amyloid aggregation in the brains of patients with AD (Xiong et al., 2008; Ruffin et al., 2014).

\section{CONCLUSION}

Intracellular $\mathrm{Ca}^{2+}$ and $\mathrm{pH}$ regulation play vital roles in both physiological and pathological conditions. Abnormal changes in $\mathrm{Ca}^{2+}$ or $\mathrm{pH}$ typically cause cell death. TRP channels are involved in $\mathrm{Ca}^{2+}$ influx, which affects neuronal and glial functions under normal physiological conditions. However, altered expression of TRP channels can lead to excess $\mathrm{Ca}^{2+}$ influx, and intracellular $\mathrm{Ca}^{2+}$ overload is maintained due to ATP2B2, oxidation, and aging-related downregulation of PMCA, leading to $\mathrm{Ca}^{2+}$-dependent cell death. Alternatively, overexpression of PMCA due to cytoplasmic $\mathrm{Ca}^{2+}$ overload causes continuous acidification from inhibition of the $\mathrm{pH}_{\mathrm{i}}$ recovery mechanisms by oxidative stress or programmed cell death, resulting in acidification-dependent cell death (Figure 2) (Harguindey et al., 2017, 2019). To date, TRP channels have been investigated for their role in NDs. However, targeting TRP channels and PMCA, including $\mathrm{Ca}^{2+}$ and $\mathrm{pH}$ regulation, as a treatment for NDs requires a deeper understanding of their function in both health and disease. This review describes potential therapeutic targets for NDs by discussing TRP channels and PMCA responsible for the disruption of intracellular $\mathrm{Ca}^{2+}$ and $\mathrm{pH}$ homeostasis that underpin ND development.

\section{AUTHOR CONTRIBUTIONS}

$\mathrm{C}-\mathrm{KP}$ and $\mathrm{YK}$ conceived and supervised the project. S-MH, JL, $\mathrm{C}-\mathrm{KP}$, and YK wrote the paper. All authors contributed to the article and approved the submitted version.

\section{FUNDING}

This work was supported by grants from the National Research Foundation of Korea (NRF-2017M3C7A1025602 and NRF-2019R1C1C1010822). 


\section{REFERENCES}

Aarts, M. M., and Tymianski, M. (2005). TRPMs and neuronal cell death. Pflugers Arch. 451, 243-249. doi: 10.1007/s00424-005-1439-x

Adachi, N., Kobayashi, T., Takahashi, H., Kawasaki, T., Shirai, Y., Ueyama, T., et al. (2008). Enzymological analysis of mutant protein kinase Cgamma causing spinocerebellar ataxia type 14 and dysfunction in Ca2+ homeostasis. J. Biol. Chem. 283, 19854-19863. doi: 10.1074/jbc.M801492200

Akyuva, Y., and Naziroglu, M. (2020). Resveratrol attenuates hypoxiainduced neuronal cell death, inflammation and mitochondrial oxidative stress by modulation of TRPM2 channel. Sci. Rep. 10:6449. doi: 10.1038/s41598-020-63577-5

Alavi, M. S., Shamsizadeh, A., Karimi, G., and Roohbakhsh, A. (2020). Transient receptor potential ankyrin 1 (TRPA1)-mediated toxicity: friend or foe? Toxicol. Mech. Methods 30, 1-18. doi: 10.1080/15376516.2019.1652872

Annunziato, L., Boscia, F., and Pignataro, G. (2013). Ionic transporter activity in astrocytes, microglia, and oligodendrocytes during brain ischemia. J. Cereb. Blood Flow Metab. 33, 969-982. doi: 10.1038/jcbfm.2013.44

Asrar, S., and Aarts, M. (2013). TRPM7, the cytoskeleton and neuronal death. Channels (Austin) 7, 6-16. doi: 10.4161/chan.22824

Auer-Grumbach, M., Olschewski, A., Papic, L., Kremer, H., Mcentagart, M. E., Uhrig, S., et al. (2010). Alterations in the ankyrin domain of TRPV4 cause congenital distal SMA, scapuloperoneal SMA and HMSN2C. Nat. Genet. 42, 160-164. doi: $10.1038 / \mathrm{ng} .508$

Bagur, R., and Hajnoczky, G. (2017). Intracellular $\mathrm{Ca}(2+)$ Sensing: its role in calcium homeostasis and signaling. Mol. Cell 66, 780-788. doi: 10.1016/j.molcel.2017.05.028

Balleza-Tapia, H., Crux, S., Andrade-Talavera, Y., Dolz-Gaiton, P., Papadia, D., Chen, G., et al. (2018). TrpV1 receptor activation rescues neuronal function and network gamma oscillations from Abeta-induced impairment in mouse hippocampus in vitro. Elife 7:37703. doi: 10.7554/eLife.37703.025

Belrose, J. C., and Jackson, M. F. (2018). TRPM2: a candidate therapeutic target for treating neurological diseases. Acta Pharmacol. Sin. 39, 722-732. doi: 10.1038 /aps.2018.31

Berridge, M. J., Lipp, P., and Bootman, M. D. (2000). The versatility and universality of calcium signalling. Nat. Rev. Mol. Cell Biol. 1, 11-21. doi: $10.1038 / 35036035$

Berrocal, M., Caballero-Bermejo, M., Gutierrez-Merino, C., and Mata, A. M. (2019). Methylene blue blocks and reverses the inhibitory effect of tau on PMCA function. Int. J. Mol. Sci. 20:3521. doi: 10.3390/ijms20143521

Bezprozvanny, I. B. (2010). Calcium signaling and neurodegeneration. Acta Naturae 2, 72-82. doi: 10.32607/20758251-2010-2-1-72-80

Boczek, T., Radzik, T., Ferenc, B., and Zylinska, L. (2019). The puzzling role of neuron-specific PMCA isoforms in the aging process. Int. J. Mol. Sci. 20:6338. doi: $10.3390 / \mathrm{ijms} 20246338$

Bolcskei, K., Kriszta, G., Saghy, E., Payrits, M., Sipos, E., Vranesics, A., et al. (2018). Behavioural alterations and morphological changes are attenuated by the lack of TRPAl receptors in the cuprizone-induced demyelination model in mice. J. Neuroimmunol. 320, 1-10. doi: 10.1016/j.jneuroim.2018. 03.020

Bollimuntha, S., Ebadi, M., and Singh, B. B. (2006). TRPC1 protects human SHSY5Y cells against salsolinol-induced cytotoxicity by inhibiting apoptosis. Brain Res. 1099, 141-149. doi: 10.1016/j.brainres.2006.04.104

Bollimuntha, S., Selvaraj, S., and Singh, B. B. (2011). Emerging roles of canonical TRP channels in neuronal function. Adv. Exp. Med. Biol. 704, 573-593. doi: 10.1007/978-94-007-0265-3_31

Bollimuntha, S., Singh, B. B., Shavali, S., Sharma, S. K., and Ebadi, M. (2005). TRPC1-mediated inhibition of 1-methyl-4-phenylpyridinium ion neurotoxicity in human SH-SY5Y neuroblastoma cells. J. Biol. Chem. 280, 2132-2140. doi: 10.1074/jbc.M407384200

Bose, T., Cieslar-Pobuda, A., and Wiechec, E. (2015). Role of ion channels in regulating $\mathrm{Ca}(2)(+)$ homeostasis during the interplay between immune and cancer cells. Cell Death Dis. 6:e1648.

Bosson, A., Paumier, A., Boisseau, S., Jacquier-Sarlin, M., Buisson, A., and Albrieux, M. (2017). TRPA1 channels promote astrocytic $\mathrm{Ca}(2+)$ hyperactivity and synaptic dysfunction mediated by oligomeric forms of amyloid-beta peptide. Mol. Neurodegener. 12:53. doi: 10.1186/s13024-0170194-8
Brini, M., Cali, T., Ottolini, D., and Carafoli, E. (2013). The plasma membrane calcium pump in health and disease. FEBS J. 280, 5385-5397. doi: $10.1111 /$ febs. 12193

Broker-Lai, J., Kollewe, A., Schindeldecker, B., Pohle, J., Nguyen Chi, V., Mathar, I., et al. (2017). Heteromeric channels formed by TRPC1, TRPC4 and TRPC5 define hippocampal synaptic transmission and working memory. EMBO J. 36, 2770-2789. doi: 10.15252/embj.201696369

Butenko, O., Dzamba, D., Benesova, J., Honsa, P., Benfenati, V., Rusnakova, V., et al. (2012). The increased activity of TRPV4 channel in the astrocytes of the adult rat hippocampus after cerebral hypoxia/ischemia. PLoS ONE 7:e39959. doi: 10.1371/journal.pone.0039959

Cali, T., Lopreiato, R., Shimony, J., Vineyard, M., Frizzarin, M., Zanni, G., et al. (2015). A novel mutation in isoform 3 of the plasma membrane $\mathrm{Ca} 2+$ pump impairs cellular $\mathrm{Ca} 2+$ homeostasis in a patient with cerebellar ataxia and laminin subunit 1alpha mutations. J. Biol. Chem. 290, 16132-16141. doi: 10.1074/jbc.M115.656496

Casey, J. R., Grinstein, S., and Orlowski, J. (2010). Sensors and regulators of intracellular pH. Nat. Rev. Mol. Cell Biol. 11, 50-61. doi: 10.1038/nrm2820

Chaste, P., and Leboyer, M. (2012). Autism risk factors: genes, environment, and gene-environment interactions. Dialogues Clin. Neurosci. 14, 281-292. doi: 10.31887/DCNS.2012.14.3/pchaste

Chen, D. H., Sul, Y., Weiss, M., Hillel, A., Lipe, H., Wolff, J., et al. (2010). CMT2C with vocal cord paresis associated with short stature and mutations in the TRPV4 gene. Neurology 75, 1968-1975. doi: 10.1212/WNL.0b013e3181ffe4bb

Chen, X., Numata, T., Li, M., Mori, Y., Orser, B. A., Jackson, M. F., et al. (2010). The modulation of TRPM7 currents by nafamostat mesilate depends directly upon extracellular concentrations of divalent cations. Mol. Brain 3:38. doi: 10.1186/1756-6606-3-38

Chesler, M. (2003). Regulation and modulation of pH in the brain. Physiol. Rev. 83, 1183-1221. doi: 10.1152/physrev.00010.2003

Chi, H., Chang, H. Y., and Sang, T. K. (2018). Neuronal cell death mechanisms in major neurodegenerative diseases. Int. J. Mol. Sci. 19:3082. doi: $10.3390 /$ ijms 19103082

Clement, D., Goodridge, J. P., Grimm, C., Patel, S., and Malmberg, K. J. (2020). TRP channels as interior designers: remodeling the endolysosomal compartment in natural killer cells. Front. Immunol. 11:753. doi: $10.3389 /$ fimmu.2020.00753

Coombes, E., Jiang, J., Chu, X. P., Inoue, K., Seeds, J., Branigan, D., et al. (2011). Pathophysiologically relevant levels of hydrogen peroxide induce glutamate-independent neurodegeneration that involves activation of transient receptor potential melastatin 7 channels. Antioxid. Redox Signal 14, 1815-1827. doi: 10.1089 /ars.2010.3549

Cornillot, M., Giacco, V., and Hamilton, N. B. (2019). The role of TRP channels in white matter function and ischaemia. Neurosci. Lett. 690, 202-209. doi: $10.1016 /$ j.neulet.2018.10.042

Cross, J. L., Meloni, B. P., Bakker, A. J., Lee, S., and Knuckey, N. W. (2010). Modes of neuronal calcium entry and homeostasis following cerebral ischemia. Stroke Res. Treat. 2010:316862. doi: 10.4061/2010/316862

Cuomo, O., Vinciguerra, A., Cerullo, P., Anzilotti, S., Brancaccio, P., Bilo, L., et al. (2015). Ionic homeostasis in brain conditioning. Front. Neurosci. 9:277. doi: 10.3389/fnins.2015.00277

Dhaka, A., Uzzell, V., Dubin, A. E., Mathur, J., Petrus, M., Bandell, M., et al. (2009). TRPV1 is activated by both acidic and basic pH. J. Neurosci. 29, 153-158. doi: 10.1523/JNEUROSCI.4901-08.2009

Douglas, R. M., Xue, J., Chen, J. Y., Haddad, C. G., Alper, S. L., and Haddad, G. G. (2003). Chronic intermittent hypoxia decreases the expression of $\mathrm{Na} / \mathrm{H}$ exchangers and HCO3-dependent transporters in mouse CNS. J. Appl. Physiol. 95, 292-299. doi: 10.1152/japplphysiol.01089.2002

Empson, R. M., Akemann, W., and Knopfel, T. (2010). The role of the calcium transporter protein plasma membrane calcium ATPase PMCA2 in cerebellar Purkinje neuron function. Funct. Neurol. 25, 153-158.

Enders, M., Heider, T., Ludwig, A., and Kuerten, S. (2020). Strategies for neuroprotection in multiple sclerosis and the role of calcium. Int. J. Mol. Sci. 21:1663. doi: 10.3390/ijms21051663

Fatemi, S. H., Aldinger, K. A., Ashwood, P., Bauman, M. L., Blaha, C. D., Blatt, G. J., et al. (2012). Consensus paper: pathological role of the cerebellum in autism. Cerebellum 11, 777-807. doi: 10.1007/s12311-01 2-0355-9 
Fernandes, E. S., Fernandes, M. A., and Keeble, J. E. (2012). The functions of TRPA1 and TRPV1: moving away from sensory nerves. Br. J. Pharmacol. 166, 510-521. doi: 10.1111/j.1476-5381.2012.01851.x

Fonfria, E., Marshall, I. C., Boyfield, I., Skaper, S. D., Hughes, J. P., Owen, D. E., et al. (2005). Amyloid beta-peptide(1-42) and hydrogen peroxide-induced toxicity are mediated by TRPM2 in rat primary striatal cultures. J. Neurochem. 95, 715-723. doi: 10.1111/j.1471-4159.2005.03396.x

Fowler, M. A., Sidiropoulou, K., Ozkan, E. D., Phillips, C. W., and Cooper, D. C. (2007). Corticolimbic expression of TRPC4 and TRPC5 channels in the rodent brain. PLoS ONE 2:e573. doi: 10.1371/journal.pone.0000573

Fresu, L., Dehpour, A., Genazzani, A. A., Carafoli, E., and Guerini, D. (1999). Plasma membrane calcium ATPase isoforms in astrocytes. Glia 28, 150-155. doi: 10.1002/(SICI)1098-1136(199911)28:2<150::AID-GLIA6>3.0.CO;2-7

Fu, M., Xie, Z., and Zuo, H. (2009). TRPV1: a potential target for antiepileptogenesis. Med. Hypotheses 73, 100-102. doi: 10.1016/j.mehy.2009.01.005

Gees, M., Colsoul, B., and Nilius, B. (2010). The role of transient receptor potential cation channels in Ca2+ signaling. Cold Spring Harb. Perspect. Biol. 2:a003962. doi: $10.1101 /$ cshperspect.a003962

Gibson, H. E., Edwards, J. G., Page, R. S., Van Hook, M. J., and Kauer, J. A. (2008). TRPV1 channels mediate long-term depression at synapses on hippocampal interneurons. Neuron 57, 746-759. doi: 10.1016/j.neuron.2007.12.027

Gilbert, J., and Man, H. Y. (2017). Fundamental elements in autism: from neurogenesis and neurite growth to synaptic plasticity. Front. Cell. Neurosci. 11:359. doi: 10.3389/fncel.2017.00359

Gleichmann, M., and Mattson, M. P. (2011). Neuronal calcium homeostasis and dysregulation. Antioxid. Redox Signal 14, 1261-1273. doi: 10.1089/ars.2010.3386

Hajieva, P., Baeken, M. W., and Moosmann, B. (2018). The role of Plasma Membrane Calcium ATPases (PMCAs) in neurodegenerative disorders. Neurosci. Lett. 663, 29-38. doi: 10.1016/j.neulet.2017.09.033

Hamakawa, H., Murashita, J., Yamada, N., Inubushi, T., Kato, N., and Kato, T. (2004). Reduced intracellular $\mathrm{pH}$ in the basal ganglia and whole brain measured by 31P-MRS in bipolar disorder. Psychiatry Clin. Neurosci. 58, 82-88. doi: 10.1111/j.1440-1819.2004.01197.x

Harguindey, S., Polo Orozco, J., Alfarouk, K. O., and Devesa, J. (2019). Hydrogen ion dynamics of cancer and a new molecular, biochemical and metabolic approach to the etiopathogenesis and treatment of brain malignancies. Int. J. Mol. Sci. 20:4278. doi: 10.3390/ijms20174278

Harguindey, S., Reshkin, S. J., Orive, G., Arranz, J. L., and Anitua, E. (2007). Growth and trophic factors, $\mathrm{pH}$ and the $\mathrm{Na}+/ \mathrm{H}+$ exchanger in Alzheimer's disease, other neurodegenerative diseases and cancer: new therapeutic possibilities and potential dangers. Curr. Alzheimer Res. 4, 53-65. doi: 10.2174/156720507779939841

Harguindey, S., Stanciu, D., Devesa, J., Alfarouk, K., Cardone, R. A., Polo Orozco, J. D., et al. (2017). Cellular acidification as a new approach to cancer treatment and to the understanding and therapeutics of neurodegenerative diseases. Semin. Cancer Biol. 43, 157-179. doi: 10.1016/j.semcancer.2017.02.003

Hasan, R., and Zhang, X. (2018). Ca(2+) regulation of TRP ion channels. Int. J. Mol. Sci. 19:1256. doi: 10.3390/ijms19041256

Hassan, S., Eldeeb, K., Millns, P. J., Bennett, A. J., Alexander, S. P., and Kendall, D. A. (2014). Cannabidiol enhances microglial phagocytosis via transient receptor potential (TRP) channel activation. Br. J. Pharmacol. 171, 2426-2439. doi: $10.1111 /$ bph. 12615

Hellmich, U. A., and Gaudet, R. (2014). Structural biology of TRP channels. Handb. Exp. Pharmacol. 223, 963-990. doi: 10.1007/978-3-319-05161-1_10

Hentschke, M., Wiemann, M., Hentschke, S., Kurth, I., Hermans-Borgmeyer, I., Seidenbecher, T., et al. (2006). Mice with a targeted disruption of the Cl/HCO3- exchanger AE3 display a reduced seizure threshold. Mol. Cell. Biol. 26, 182-191. doi: 10.1128/MCB.26.1.182-191.2006

Hermosura, M. C., Cui, A. M., Go, R. C., Davenport, B., Shetler, C. M., Heizer, J. W., et al. (2008). Altered functional properties of a TRPM2 variant in Guamanian ALS and PD. Proc. Natl. Acad. Sci. U. S. A. 105, 18029-18034. doi: 10.1073/pnas.0808218105

Hermosura, M. C., Nayakanti, H., Dorovkov, M. V., Calderon, F. R., Ryazanov, A. G., Haymer, D. S., et al. (2005). A TRPM7 variant shows altered sensitivity to magnesium that may contribute to the pathogenesis of two Guamanian neurodegenerative disorders. Proc. Natl. Acad. Sci. U. S. A. 102, 11510-11515 doi: 10.1073/pnas.0505149102

Ho, K. W., Lambert, W. S., and Calkins, D. J. (2014). Activation of the TRPV1 cation channel contributes to stress-induced astrocyte migration. Glia 62, 1435-1451. doi: 10.1002/glia.22691

Ho, K. W., Ward, N. J., and Calkins, D. J. (2012). TRPV1: a stress response protein in the central nervous system. Am. J. Neurodegener. Dis. 1, 1-14.

Hong, C., Jeong, B., Park, H. J., Chung, J. Y., Lee, J. E., Kim, J., et al. (2020). TRP channels as emerging therapeutic targets for neurodegenerative diseases. Front. Physiol. 11:238. doi: 10.3389/fphys.2020.00238

Hong, C., Seo, H., Kwak, M., Jeon, J., Jang, J., Jeong, E. M., et al. (2015). Increased TRPC5 glutathionylation contributes to striatal neuron loss in Huntington's disease. Brain 138, 3030-3047. doi: 10.1093/brain/awv188

Huang, J., Du, W., Yao, H., and Wang, Y. (2011). "TRPC channels in neuronal survival," in TRP Channels, ed M. X. Zhu (Boca Raton, FL: CRC Press/Taylor \& Francis), 1-23.

Huang, S., Turlova, E., Li, F., Bao, M. H., Szeto, V., Wong, R., et al. (2017). Transient receptor potential melastatin 2 channels (TRPM2) mediate neonatal hypoxic-ischemic brain injury in mice. Exp. Neurol. 296, 32-40. doi: 10.1016/j.expneurol.2017.06.023

Huang, Y., Fliegert, R., Guse, A. H., Lu, W., and Du, J. (2020). A structural overview of the ion channels of the TRPM family. Cell Calcium 85:102111. doi: 10.1016/j.ceca.2019.102111

Hwang, S. M., Koo, N. Y., Jin, M., Davies, A. J., Chun, G. S., Choi, S. Y., et al. (2011). Intracellular acidification is associated with changes in free cytosolic calcium and inhibition of action potentials in rat trigeminal ganglion. J. Biol. Chem. 286, 1719-1729. doi: 10.1074/jbc.M109.090951

Jardin, I., Lopez, J. J., Diez, R., Sanchez-Collado, J., Cantonero, C., Albarran, L., et al. (2017). TRPs in pain sensation. Front. Physiol. 8:392. doi: $10.3389 /$ fphys.2017.00392

Jiang, L., Bechtel, M. D., Galeva, N. A., Williams, T. D., Michaelis, E. K., and Michaelis, M. L. (2012). Decreases in plasma membrane Ca(2)(+)-ATPase in brain synaptic membrane rafts from aged rats. J. Neurochem. 123, 689-699. doi: 10.1111/j.1471-4159.2012.07918.x

Kaczmarek, J. S., Riccio, A., and Clapham, D. E. (2012). Calpain cleaves and activates the TRPC5 channel to participate in semaphorin 3A-induced neuronal growth cone collapse. Proc. Natl. Acad. Sci. U. S. A. 109, 7888-7892. doi: 10.1073/pnas.1205869109

Kaneko, S., Kawakami, S., Hara, Y., Wakamori, M., Itoh, E., Minami, T., et al. (2006). A critical role of TRPM2 in neuronal cell death by hydrogen peroxide. J. Pharmacol. Sci. 101, 66-76. doi: 10.1254/jphs.FP0060128

Kaneko, Y., and Szallasi, A. (2014). Transient receptor potential (TRP) channels: a clinical perspective. Br. J. Pharmacol. 171, 2474-2507. doi: 10.1111/bph.12414

Kato, T., Murashita, J., Kamiya, A., Shioiri, T., Kato, N., and Inubushi, T. (1998). Decreased brain intracellular pH measured by 31P-MRS in bipolar disorder: a confirmation in drug-free patients and correlation with white matter hyperintensity. Eur. Arch. Psychiatry Clin. Neurosci. 248, 301-306. doi: 10.1007/s004060050054

Kawamoto, E. M., Vivar, C., and Camandola, S. (2012). Physiology and pathology of calcium signaling in the brain. Front. Pharmacol. 3:61. doi: 10.3389/fphar.2012.00061

Kim, S. R., Bok, E., Chung, Y. C., Chung, E. S., and Jin, B. K. (2008). Interactions between $\mathrm{CB}(1)$ receptors and TRPV1 channels mediated by 12-HPETE are cytotoxic to mesencephalic dopaminergic neurons. Br. J. Pharmacol. 155, 253-264. doi: 10.1038/bjp.2008.246

Kim, S. R., Kim, S. U., Oh, U., and Jin, B. K. (2006). Transient receptor potential vanilloid subtype 1 mediates microglial cell death in vivo and in vitro via $\mathrm{Ca} 2+-$ mediated mitochondrial damage and cytochrome c release. J. Immunol. 177, 4322-4329. doi: 10.4049/jimmunol.177.7.4322

Kim, S. R., Lee, D. Y., Chung, E. S., Oh, U. T., Kim, S. U., and Jin, B. K. (2005). Transient receptor potential vanilloid subtype 1 mediates cell death of mesencephalic dopaminergic neurons in vivo and in vitro. J. Neurosci. 25, 662-671. doi: 10.1523/JNEUROSCI.4166-04.2005

Kip, S. N., Gray, N. W., Burette, A., Canbay, A., Weinberg, R. J., and Strehler, E. E. (2006). Changes in the expression of plasma membrane calcium extrusion systems during the maturation of hippocampal neurons. Hippocampus 16, 20-34. doi: 10.1002/hipo.20129 
Klein, C. J., Shi, Y., Fecto, F., Donaghy, M., Nicholson, G., Mcentagart, M. E., et al. (2011). TRPV4 mutations and cytotoxic hypercalcemia in axonal Charcot-Marie-Tooth neuropathies. Neurology 76, 887-894. doi: 10.1212/WNL.0b013e31820f2de3

Kumar, A., Bodhinathan, K., and Foster, T. C. (2009). Susceptibility to calcium dysregulation during brain aging. Front. Aging Neurosci. 1:2. doi: 10.3389/neuro.24.002.2009

Kumar, P., Kumar, D., Jha, S. K., Jha, N. K., and Ambasta, R. K. (2016). Ion channels in neurological disorders. Adv. Protein Chem. Struct. Biol. 103, 97-136. doi: 10.1016/bs.apcsb.2015.10.006

Kurnellas, M. P., Lee, A. K., Szczepanowski, K., and Elkabes, S. (2007). Role of plasma membrane calcium ATPase isoform 2 in neuronal function in the cerebellum and spinal cord. Ann. N. Y. Acad. Sci. 1099, 287-291. doi: 10.1196/annals.1387.025

Landoure, G., Zdebik, A. A., Martinez, T. L., Burnett, B. G., Stanescu, H. C., Inada, H., et al. (2010). Mutations in TRPV4 cause Charcot-Marie-Tooth disease type 2C. Nat. Genet. 42, 170-174. doi: 10.1038/ng.512

Lastres-Becker, I., De Miguel, R., De Petrocellis, L., Makriyannis, A., Di Marzo, V., and Fernandez-Ruiz, J. (2003). Compounds acting at the endocannabinoid and/or endovanilloid systems reduce hyperkinesia in a rat model of Huntington's disease. J. Neurochem. 84, 1097-1109. doi: 10.1046/j.1471-4159.2003.01595.x

Lee, K. I., Lee, H. T., Lin, H. C., Tsay, H. J., Tsai, F. C., Shyue, S. K., et al. (2016). Role of transient receptor potential ankyrin 1 channels in Alzheimer's disease. J. Neuroinflammation 13:92. doi: 10.1186/s12974-016-0557-z

Lee, T. H., Lee, J. G., Yon, J. M., Oh, K. W., Baek, I. J., Nahm, S. S., et al. (2011). Capsaicin prevents kainic acid-induced epileptogenesis in mice. Neurochem. Int. 58, 634-640. doi: 10.1016/j.neuint.2011.01.027

Lessard, C. B., Lussier, M. P., Cayouette, S., Bourque, G., and Boulay, G. (2005). The overexpression of presenilin2 and Alzheimer's-disease-linked presenilin2 variants influences TRPC6-enhanced Ca2+ entry into HEK293 cells. Cell. Signal 17, 437-445. doi: 10.1016/j.cellsig.2004.09.005

Li, H. B., Mao, R. R., Zhang, J. C., Yang, Y., Cao, J., and Xu, L. (2008). Antistress effect of TRPV1 channel on synaptic plasticity and spatial memory. Biol. Psychiatry 64, 286-292. doi: 10.1016/j.biopsych.2008.02.020

Li, W., Calfa, G., Larimore, J., and Pozzo-Miller, L. (2012). Activity-dependent BDNF release and TRPC signaling is impaired in hippocampal neurons of Mecp2 mutant mice. Proc. Natl. Acad. Sci. U. S. A. 109, 17087-17092. doi: $10.1073 /$ pnas. 1205271109

Liedtke, W., and Friedman, J. M. (2003). Abnormal osmotic regulation in trpv4-/- mice. Proc. Natl. Acad. Sci. U. S. A. 100, 13698-13703. doi: 10.1073/pnas.1735416100

Liu, N., Wu, J., Chen, Y., and Zhao, J. (2020). Channels that cooperate with TRPV4 in the brain. J. Mol. Neurosci. 70, 1812-1820. doi: 10.1007/s12031-020-01574-Z

Liu, N., Zhuang, Y., Zhou, Z., Zhao, J., Chen, Q., and Zheng, J. (2017). NF-kappaB dependent up-regulation of TRPC6 by Abeta in BV-2 microglia cells increases COX-2 expression and contributes to hippocampus neuron damage. Neurosci. Lett. 651, 1-8. doi: 10.1016/j.neulet.2017.04.056

Logashina, Y. A., Korolkova, Y. V., Kozlov, S. A., and Andreev, Y. A. (2019). TRPA1 channel as a regulator of neurogenic inflammation and pain: structure, function, role in pathophysiology, and therapeutic potential of ligands. Biochemistry Mosc. 84, 101-118. doi: 10.1134/S00062979190 20020

Lu, R., He, Q., and Wang, J. (2017). TRPC channels and Alzheimer's disease. Adv. Exp. Med. Biol. 976, 73-83. doi: 10.1007/978-94-024-1088-4_7

Luo, L., Song, S., Ezenwukwa, C. C., Jalali, S., Sun, B., and Sun, D. (2020). Ion channels and transporters in microglial function in physiology and brain diseases. Neurochem. Int. 142:104925. doi: 10.1016/j.neuint.2020.104925

Majdi, A., Mahmoudi, J., Sadigh-Eteghad, S., Golzari, S. E., Sabermarouf, B., and Reyhani-Rad, S. (2016). Permissive role of cytosolic $\mathrm{pH}$ acidification in neurodegeneration: a closer look at its causes and consequences. J. Neurosci. Res. 94, 879-887. doi: 10.1002/jnr.23757

Maklad, A., Sharma, A., and Azimi, I. (2019). Calcium signaling in brain cancers: roles and therapeutic targeting. Cancers 11:145. doi: 10.3390/cancers11020145

Mandal, P. K., Akolkar, H., and Tripathi, M. (2012). Mapping of hippocampal $\mathrm{pH}$ and neurochemicals from in vivo multi-voxel 31P study in healthy normal young male/female, mild cognitive impairment, and Alzheimer's disease. J. Alzheimers Dis. 31, S75-86. doi: 10.3233/JAD-2012-120166
Marambaud, P., Dreses-Werringloer, U., and Vingtdeux, V. (2009). Calcium signaling in neurodegeneration. Mol. Neurodegener. 4:20. doi: 10.1186/1750-1326-4-20

Mazzitelli, L. R., and Adamo, H. P. (2014). Hyperactivation of the human plasma membrane Ca2+ pump PMCA h4xb by mutation of Glu99 to Lys. J. Biol. Chem. 289, 10761-10768. doi: 10.1074/jbc.M113.535583

Mickle, A. D., Shepherd, A. J., and Mohapatra, D. P. (2015). Sensory TRP channels: the key transducers of nociception and pain. Prog. Mol. Biol. Transl. Sci. 131, 73-118. doi: 10.1016/bs.pmbts.2015.01.002

Minke, B. (2006). TRP channels and Ca2+ signaling. Cell Calcium 40, 261-275. doi: 10.1016/j.ceca.2006.05.002

Mizoguchi, Y., Kato, T. A., Seki, Y., Ohgidani, M., Sagata, N., Horikawa, H., et al. (2014). Brain-derived neurotrophic factor (BDNF) induces sustained intracellular $\mathrm{Ca} 2+$ elevation through the up-regulation of surface transient receptor potential 3 (TRPC3) channels in rodent microglia. J. Biol. Chem. 289, 18549-18555. doi: 10.1074/jbc.M114.555334

Moran, M. M. (2018). TRP channels as potential drug targets. Annu. Rev. Pharmacol. Toxicol. 58, 309-330. doi: 10.1146/annurev-pharmtox-010617-052832

Moran, M. M., Xu, H., and Clapham, D. E. (2004). TRP ion channels in the nervous system. Curr. Opin. Neurobiol. 14, 362-369. doi: 10.1016/j.conb.2004.05.003

Morelli, M. B., Amantini, C., Liberati, S., Santoni, M., and Nabissi, M. (2013). TRP channels: new potential therapeutic approaches in CNS neuropathies. CNS Neurol. Disord. Drug Targets 12, 274-293. doi: 10.2174/18715273113129990056

Neuner, S. M., Wilmott, L. A., Hope, K. A., Hoffmann, B., Chong, J. A., Abramowitz, J., et al. (2015). TRPC3 channels critically regulate hippocampal excitability and contextual fear memory. Behav. Brain Res. 281, 69-77. doi: $10.1016 /$ j.bbr.2014.12.018

Nikoletopoulou, V., and Tavernarakis, N. (2012). Calcium homeostasis in aging neurons. Front. Genet. 3:200. doi: 10.3389/fgene.2012.00200

Nilius, B. (2007). TRP channels in disease. Biochim. Biophys. Acta 1772, 805-812. doi: 10.1016/j.bbadis.2007.02.002

Nilius, B., and Owsianik, G. (2011). The transient receptor potential family of ion channels. Genome Biol. 12:218. doi: 10.1186/gb-2011-12-3-218

Nilius, B., Prenen, J., and Owsianik, G. (2011). Irritating channels: the case of TRPA1. J. Physiol. 589, 1543-1549. doi: 10.1113/jphysiol.2010.200717

Nishida, M., Kuwahara, K., Kozai, D., Sakaguchi, R., and Mori, Y. (2015). "TRP channels: their function and potentiality as drug targets," in Innovative Medicine: Basic Research and Development, eds K. Nakao, N. Minato, and S. Uemoto (Tokyo: Springer), 195-218. doi: 10.1007/978-4-431-55651-0_17

Oakes, M., Law, W. J., and Komuniecki, R. (2019). Cannabinoids stimulate the trp channel-dependent release of both serotonin and dopamine to modulate behavior in C. elegans. J. Neurosci. 39, 4142-4152. doi: 10.1523/JNEUROSCI.2371-18.2019

Ostapchenko, V. G., Chen, M., Guzman, M. S., Xie, Y. F., Lavine, N., Fan, J., et al. (2015). The Transient Receptor Potential Melastatin 2 (TRPM2) channel contributes to beta-amyloid oligomer-related neurotoxicity and memory impairment. J. Neurosci. 35, 15157-15169. doi: 10.1523/JNEUROSCI.4081-14.2015

Parker, M. D., and Boron, W. F. (2013). The divergence, actions, roles, and relatives of sodium-coupled bicarbonate transporters. Physiol. Rev. 93, 803-959. doi: $10.1152 /$ physrev.00023.2012

Piacentini, R., Gangitano, C., Ceccariglia, S., Del Fa, A., Azzena, G. B., Michetti, F., et al. (2008). Dysregulation of intracellular calcium homeostasis is responsible for neuronal death in an experimental model of selective hippocampal degeneration induced by trimethyltin. J. Neurochem. 105, 2109-2121. doi: 10.1111/j.1471-4159.2008.05297.x

Popugaeva, E., Pchitskaya, E., and Bezprozvanny, I. (2017). Dysregulation of neuronal calcium homeostasis in Alzheimer's disease - a therapeutic opportunity? Biochem. Biophys. Res. Commun. 483, 998-1004. doi: 10.1016/j.bbrc.2016.09.053

Pottorf, W. J. II, Johanns, T. M., Derrington, S. M., Strehler, E. E., Enyedi, A., and Thayer, S. A. (2006). Glutamate-induced protease-mediated loss of plasma membrane Ca2+ pump activity in rat hippocampal neurons. J. Neurochem. 98, 1646-1656. doi: 10.1111/j.1471-4159.2006.04063.x

Rakers, C., Schmid, M., and Petzold, G. C. (2017). TRPV4 channels contribute to calcium transients in astrocytes and neurons during peri-infarct depolarizations in a stroke model. Glia $65,1550-1561$. doi: 10.1002/glia.23183 
Riccio, A., Medhurst, A. D., Mattei, C., Kelsell, R. E., Calver, A. R., Randall, A. D., et al. (2002). mRNA distribution analysis of human TRPC family in CNS and peripheral tissues. Brain Res. Mol. Brain Res. 109, 95-104. doi: 10.1016/S0169-328X(02)00527-2

Ronco, V., Grolla, A. A., Glasnov, T. N., Canonico, P. L., Verkhratsky, A., Genazzani, A. A., et al. (2014). Differential deregulation of astrocytic calcium signalling by amyloid-beta, TNFalpha, IL-1beta and LPS. Cell Calcium 55, 219-229. doi: 10.1016/j.ceca.2014.02.016

Rosker, C., Graziani, A., Lukas, M., Eder, P., Zhu, M. X., Romanin, C., et al. (2004). $\mathrm{Ca}(2+)$ signaling by TRPC3 involves $\mathrm{Na}(+)$ entry and local coupling to the $\mathrm{Na}(+) / \mathrm{Ca}(2+)$ exchanger. J. Biol. Chem. 279, 13696-13704. doi: $10.1074 / j b c . M 308108200$

Ruffin, V. A., Salameh, A. I., Boron, W. F., and Parker, M. D. (2014). Intracellular $\mathrm{pH}$ regulation by acid-base transporters in mammalian neurons. Front. Physiol. 5:43. doi: 10.3389/fphys.2014.00043

Ryazanova, L. V., Rondon, L. J., Zierler, S., Hu, Z., Galli, J., Yamaguchi, T. P., et al. (2010). TRPM7 is essential for $\mathrm{Mg}(2+)$ homeostasis in mammals. Nat. Commun. 1:109. doi: 10.1038/ncomms1108

Saghy, E., Sipos, E., Acs, P., Bolcskei, K., Pohoczky, K., Kemeny, A., et al. (2016). TRPA1 deficiency is protective in cuprizone-induced demyelinationa new target against oligodendrocyte apoptosis. Glia 64, 2166-2180. doi: 10.1002/glia.23051

Samanta, A., Hughes, T. E. T., and Moiseenkova-Bell, V. Y. (2018). Transient receptor potential (TRP) channels. Subcell. Biochem. 87, 141-165. doi: 10.1007/978-981-10-7757-9_6

Sawamura, S., Shirakawa, H., Nakagawa, T., Mori, Y., and Kaneko, S. (2017). "TRP channels in the brain: what are they there for?", in Neurobiology of TRP Channels, ed T. L. R. Emir (Boca Raton, FL: CRC Press), 295-322. doi: 10.4324/9781315152837-16

Schmiege, P., Fine, M., and Li, X. (2018). The regulatory mechanism of mammalian TRPMLs revealed by cryo-EM. FEBS J. 285, 2579-2585. doi: 10.1111/febs.14443

Selvaraj, S., Sun, Y., and Singh, B. B. (2010). TRPC channels and their implication in neurological diseases. CNS Neurol. Disord. Drug Targets 9, 94-104. doi: 10.2174/187152710790966650

Selvaraj, S., Sun, Y., Watt, J. A., Wang, S., Lei, S., Birnbaumer, L., et al. (2012). Neurotoxin-induced ER stress in mouse dopaminergic neurons involves downregulation of TRPC1 and inhibition of AKT/mTOR signaling. J. Clin. Invest. 122, 1354-1367. doi: 10.1172/JCI61332

Selvaraj, S., Watt, J. A., and Singh, B. B. (2009). TRPC1 inhibits apoptotic cell degeneration induced by dopaminergic neurotoxin MPTP/MPP(+). Cell Calcium 46, 209-218. doi: 10.1016/j.ceca.2009. 07.008

Shigetomi, E., Tong, X., Kwan, K. Y., Corey, D. P., and Khakh, B. S. (2011). TRPA1 channels regulate astrocyte resting calcium and inhibitory synapse efficacy through GAT-3. Nat. Neurosci. 15, 70-80. doi: 10.1038/nn.3000

Shin, H. Y., Hong, Y. H., Jang, S. S., Chae, H. G., Paek, S. L., Moon, H. E., et al. (2010). A role of canonical transient receptor potential 5 channel in neuronal differentiation from A2B5 neural progenitor cells. PLoS ONE 5:e10359. doi: 10.1371/journal.pone.0010359

Shirakawa, H., Yamaoka, T., Sanpei, K., Sasaoka, H., Nakagawa, T., and Kaneko, S. (2008). TRPV1 stimulation triggers apoptotic cell death of rat cortical neurons. Biochem. Biophys. Res. Commun. 377, 1211-1215. doi: 10.1016/j.bbrc.2008.10.152

Siddiqui, T., Lively, S., Ferreira, R., Wong, R., and Schlichter, L. C. (2014). Expression and contributions of TRPM7 and KCa2.3/SK3 channels to the increased migration and invasion of microglia in anti-inflammatory activation states. PLoS ONE 9:e106087. doi: 10.1371/journal.pone.0106087

Sinning, A., and Hubner, C.A. (2013). Minireview: $\mathrm{pH}$ and synaptic transmission. FEBS Lett. 587, 1923-1928

Sita, G., Hrelia, P., Graziosi, A., Ravegnini, G., and Morroni, F. (2018). TRPM2 in the brain: role in health and disease. Cells 7:82. doi: 10.3390/cells7070082

Slanzi, A., Iannoto, G., Rossi, B., Zenaro, E., and Constantin, G. (2020). In vitro models of neurodegenerative diseases. Front. Cell Dev. Biol. 8:328. doi: $10.3389 /$ fcell. 2020.00328

Smaili, S., Hirata, H., Ureshino, R., Monteforte, P. T., Morales, A. P., Muler, M. L., et al. (2009). Calcium and cell death signaling in neurodegeneration and aging. An. Acad. Bras. Cienc. 81, 467-475. doi: 10.1590/S0001-37652009000 300011
Smits, J. J., Oostrik, J., Beynon, A. J., Kant, S. G., De Koning Gans, P. a. M., et al. (2019). De novo and inherited loss-of-function variants of ATP2B2 are associated with rapidly progressive hearing impairment. Hum. Genet. 138, 61-72. doi: 10.1007/s00439-018-1965-1

Song, J., Lee, J. H., Lee, S. H., Park, K. A., Lee, W. T., and Lee, J. E. (2013). TRPV1 activation in primary cortical neurons induces calcium-dependent programmed cell death. Exp. Neurobiol. 22, 51-57. doi: 10.5607/en.2013.22.1.51

Song, S., Luo, L., Sun, B., and Sun, D. (2020). Roles of glial ion transporters in brain diseases. Glia 68, 472-494. doi: 10.1002/glia.23699

Sprenkle, N. T., Sims, S. G., Sanchez, C. L., and Meares, G. P. (2017). Endoplasmic reticulum stress and inflammation in the central nervous system. Mol. Neurodegener. 12:42. doi: 10.1186/s13024-017-0183-y

Stafford, N., Wilson, C., Oceandy, D., Neyses, L., and Cartwright, E. J. (2017). The plasma membrane calcium ATPases and their role as major new players in human disease. Physiol. Rev. 97, 1089-1125. doi: 10.1152/physrev.00028.2016

Startek, J. B., Boonen, B., Talavera, K., and Meseguer, V. (2019). TRP channels as sensors of chemically-induced changes in cell membrane mechanical properties. Int. J. Mol. Sci. 20:371. doi: 10.3390/ijms20020371

Stauffer, T. P., Guerini, D., and Carafoli, E. (1995). Tissue distribution of the four gene products of the plasma membrane Ca2+ pump. A study using specific antibodies. J. Biol. Chem. 270, 12184-12190. doi: 10.1074/jbc.270.20.12184

Strehler, E. E., Caride, A. J., Filoteo, A. G., Xiong, Y., Penniston, J. T., and Enyedi, A. (2007). Plasma membrane Ca2+ ATPases as dynamic regulators of cellular calcium handling. Ann. N. Y. Acad. Sci. 1099, 226-236. doi: $10.1196 /$ annals. 1387.023

Strehler, E. E., and Thayer, S. A. (2018). Evidence for a role of plasma membrane calcium pumps in neurodegenerative disease: recent developments. Neurosci. Lett. 663, 39-47. doi: 10.1016/j.neulet.2017.08.035

Tai, C., Hines, D. J., Choi, H. B., and Macvicar, B. A. (2011). Plasma membrane insertion of TRPC 5 channels contributes to the cholinergic plateau potential in hippocampal CA1 pyramidal neurons. Hippocampus 21, 958-967. doi: 10.1002/hipo.20807

Tedeschi, V., Petrozziello, T., Sisalli, M. J., Boscia, F., Canzoniero, L. M. T., and Secondo, A. (2019). The activation of Mucolipin TRP channel 1 (TRPML1) protects motor neurons from L-BMAA neurotoxicity by promoting autophagic clearance. Sci. Rep. 9:10743. doi: 10.1038/s41598-019-46708-5

Thapak, P., Vaidya, B., Joshi, H. C., Singh, J. N., and Sharma, S. S. (2020). Therapeutic potential of pharmacological agents targeting TRP channels in CNS disorders. Pharmacol. Res. 159:105026. doi: 10.1016/j.phrs.2020.105026

Tyrtyshnaia, A. A., Lysenko, L. V., Madamba, F., Manzhulo, I. V., Khotimchenko, M. Y., and Kleschevnikov, A. M. (2016). Acute neuroinflammation provokes intracellular acidification in mouse hippocampus. J. Neuroinflammation 13:283. doi: 10.1186/s12974-016-0747-8

Vale-Gonzalez, C., Alfonso, A., Sunol, C., Vieytes, M. R., and Botana, L. M. (2006). Role of the plasma membrane calcium adenosine triphosphatase on domoateinduced intracellular acidification in primary cultures of cerebelar granule cells. J. Neurosci. Res. 84, 326-337. doi: 10.1002/jnr.20878

Venkatachalam, K., and Montell, C. (2007). TRP channels. Annu. Rev. Biochem. 76, 387-417. doi: 10.1146/annurev.biochem.75.103004.142819

Vennekens, R., Menigoz, A., and Nilius, B. (2012). TRPs in the brain. Rev. Physiol. Biochem. Pharmacol. 163, 27-64. doi: 10.1007/112_2012_8

Verkhratsky, A., Reyes, R. C., and Parpura, V. (2014). TRP channels coordinate ion signalling in astroglia. Rev. Physiol. Biochem. Pharmacol. 166, 1-22. doi: 10.1007/112_2013_15

Villereal, M. L. (2006). Mechanism and functional significance of TRPC channel multimerization. Semin. Cell Dev. Biol. 17, 618-629. doi: 10.1016/j.semcdb.2006.10.010

Von Spiczak, S., Muhle, H., Helbig, I., De Kovel, C. G., Hampe, J., Gaus, V., et al. (2010). Association study of TRPC4 as a candidate gene for generalized epilepsy with photosensitivity. Neuromolecular Med. 12, 292-299. doi: 10.1007/s12017-010-8122-x

Wang, H., Cheng, X., Tian, J., Xiao, Y., Tian, T., Xu, F., et al. (2020). TRPC channels: structure, function, regulation and recent advances in small molecular probes. Pharmacol. Ther. 209:107497. doi: 10.1016/j.pharmthera.2020.107497

Wang, J., Jackson, M. F., and Xie, Y. F. (2016). Glia and TRPM2 channels in plasticity of central nervous system and Alzheimer's diseases. Neural Plast. 2016:1680905. doi: 10.1155/2016/1680905 
Wang, J., Lu, R., Yang, J., Li, H., He, Z., Jing, N., et al. (2015). TRPC6 specifically interacts with APP to inhibit its cleavage by gamma-secretase and reduce Abeta production. Nat. Commun. 6:8876. doi: 10.1038/ncomms9876

Wang, M., Bianchi, R., Chuang, S. C., Zhao, W., and Wong, R. K. (2007). Group I metabotropic glutamate receptor-dependent TRPC channel trafficking in hippocampal neurons. J. Neurochem. 101, 411-421. doi: 10.1111/j.1471-4159.2006.04377.x

Wang, Z., Zhou, L., An, D., Xu, W., Wu, C., Sha, S., et al. (2019). TRPV4-induced inflammatory response is involved in neuronal death in pilocarpine model of temporal lobe epilepsy in mice. Cell Death Dis. 10:386. doi: 10.1038/s41419-019-1691-1

Wong, M. M. K., Hoekstra, S. D., Vowles, J., Watson, L. M., Fuller, G., Nemeth, A. H., et al. (2018). Neurodegeneration in SCA14 is associated with increased PKCgamma kinase activity, mislocalization and aggregation. Acta Neuropathol. Commun. 6:99. doi: 10.1186/s40478-018-0600-7

Woolums, B. M., Mccray, B. A., Sung, H., Tabuchi, M., Sullivan, J. M., Ruppell, K. T., et al. (2020). TRPV4 disrupts mitochondrial transport and causes axonal degeneration via a CaMKII-dependent elevation of intracellular $\mathrm{Ca}(2)$. Nat. Commun. 11:2679. doi: 10.1038/s41467-020-16411-5

Wu, D., Huang, W., Richardson, P. M., Priestley, J. V., and Liu, M. (2008). TRPC4 in rat dorsal root ganglion neurons is increased after nerve injury and is necessary for neurite outgrowth. J. Biol. Chem. 283, 416-426. doi: 10.1074/jbc.M703177200

Wu, X., Zagranichnaya, T. K., Gurda, G. T., Eves, E. M., and Villereal, M. L. (2004). A TRPC1/TRPC3-mediated increase in store-operated calcium entry is required for differentiation of H19-7 hippocampal neuronal cells. J. Biol. Chem. 279, 43392-43402. doi: 10.1074/jbc.M408959200

Xiong, Z. G., Pignataro, G., Li, M., Chang, S. Y., and Simon, R. P. (2008). Acidsensing ion channels (ASICs) as pharmacological targets for neurodegenerative diseases. Curr. Opin. Pharmacol. 8, 25-32. doi: 10.1016/j.coph.2007.09.001

Yamamoto, S., Wajima, T., Hara, Y., Nishida, M., and Mori, Y. (2007). Transient receptor potential channels in Alzheimer's disease. Biochim. Biophys. Acta 1772, 958-967. doi: 10.1016/j.bbadis.2007.03.006

Yamamoto, T., Swietach, P., Rossini, A., Loh, S. H., Vaughan-Jones, R. D., and Spitzer, K. W. (2005). Functional diversity of electrogenic Na+-HCO3cotransport in ventricular myocytes from rat, rabbit and guinea pig. J. Physiol. 562, 455-475. doi: 10.1113/jphysiol.2004.071068

Yang, H., and Li, S. (2016). Transient Receptor Potential Ankyrin 1 (TRPA1) channel and neurogenic inflammation in pathogenesis of asthma. Med. Sci. Monit. 22, 2917-2923. doi: 10.12659/MSM.896557

Yang, W., Liu, J., Zheng, F., Jia, M., Zhao, L., Lu, T., et al. (2013). The evidence for association of ATP2B2 polymorphisms with autism in Chinese Han population. PLoS ONE 8:e61021. doi: 10.1371/journal.pone.0061021
Zaidi, A. (2010). Plasma membrane Ca-ATPases: targets of oxidative stress in brain aging and neurodegeneration. World J. Biol. Chem. 1, 271-280. doi: 10.4331/wjbc.v1.i9.271

Zaidi, A., Adewale, M., Mclean, L., and Ramlow, P. (2018). The plasma membrane calcium pumps-the old and the new. Neurosci. Lett. 663, 12-17. doi: 10.1016/j.neulet.2017.09.066

Zanni, G., Cali, T., Kalscheuer, V. M., Ottolini, D., Barresi, S., Lebrun, N., et al. (2012). Mutation of plasma membrane Ca2 + ATPase isoform 3 in a family with X-linked congenital cerebellar ataxia impairs Ca2+ homeostasis. Proc. Natl. Acad. Sci. U. S. A. 109, 14514-14519. doi: 10.1073/pnas.1207488109

Zeng, Z., Leng, T., Feng, X., Sun, H., Inoue, K., Zhu, L., et al. (2015). Silencing TRPM7 in mouse cortical astrocytes impairs cell proliferation and migration via ERK and JNK signaling pathways. PLoS ONE 10:e0119912. doi: 10.1371/journal.pone.0119912

Zhai, K., Liskova, A., Kubatka, P., and Busselberg, D. (2020). Calcium entry through TRPV1: a potential target for the regulation of proliferation and apoptosis in cancerous and healthy cells. Int. J. Mol. Sci. 21:4177. doi: $10.3390 /$ ijms 21114177

Zhang, E., and Liao, P. (2015). Brain transient receptor potential channels and stroke. J. Neurosci. Res. 93, 1165-1183. doi: 10.1002/jnr.23529

Zhao, H., Carney, K. E., Falgoust, L., Pan, J. W., Sun, D., and Zhang, Z. (2016). Emerging roles of $\mathrm{Na}(+) / \mathrm{H}(+)$ exchangers in epilepsy and developmental brain disorders. Prog. Neurobiol. 138-140, 19-35. doi: 10.1016/j.pneurobio.2016.02.002

Zheng, J. (2013). Molecular mechanism of TRP channels. Compr. Physiol. 3, 221-242. doi: 10.1002/cphy.c120001

Zundorf, G., and Reiser, G. (2011). Calcium dysregulation and homeostasis of neural calcium in the molecular mechanisms of neurodegenerative diseases provide multiple targets for neuroprotection. Antioxid. Redox Signal 14, 1275-1288. doi: 10.1089/ars.2010. 3359

Conflict of Interest: The authors declare that the research was conducted in the absence of any commercial or financial relationships that could be construed as a potential conflict of interest.

Copyright (c) 2021 Hwang, Lee, Park and Kim. This is an open-access article distributed under the terms of the Creative Commons Attribution License (CC BY). The use, distribution or reproduction in other forums is permitted, provided the original author(s) and the copyright owner(s) are credited and that the original publication in this journal is cited, in accordance with accepted academic practice. No use, distribution or reproduction is permitted which does not comply with these terms. 